\title{
Central African Economic and Monetary Community: Staff Report on Common Policies of Member Countries; Public Information Notice on the Executive Board Discussion; and Statement by the Executive Director for the Central African Economic and Monetary Community
}

In the context of the 2011 Article IV consultations with the countries forming the Central African Economic and Monetary Community (CEMAC), the following documents have been released and are included in this package:

- $\quad$ The staff report on Common Policies of Member Countries of the CEMAC, prepared by a staff team of the IMF, following discussions that ended on April 1, 2011, with the officials of the CEMAC on economic developments and policies. Based on information available at the time of these discussions, the staff report was completed on July 5, 2011. The views expressed in the staff report are those of the staff team and do not necessarily reflect the views of the Executive Board of the IMF.

- $\quad$ A Public Information Notice (PIN) summarizing the views of the Executive Board as expressed during its July 20, 2011 discussion of the staff report.

- A statement by the Executive Director on the common policies of member countries in the CEMAC.

The policy of publication of staff reports and other documents allows for the deletion of market-sensitive information.

$$
\begin{gathered}
\text { Copies of this report are available to the public from } \\
\text { International Monetary Fund • Publication Services } \\
70019^{\text {th }} \text { Street, N.W. • Washington, D.C. } 20431 \\
\text { Telephone: (202) 623-7430 • Telefax: (202) 623-7201 } \\
\text { E-mail: publications@imf.org Internet: http://www.imf.org }
\end{gathered}
$$

\section{International Monetary Fund Washington, D.C.}


INTERNATIONAL MONETARY FUND

\section{Central African Economic and Monetary Community Staff Report on Common Policies of Member Countries}

\section{Regional Consultation on Economic Issues and Policies ${ }^{1}$}

Prepared by the African Department

(In consultation with other departments)

Approved by Sharmini Coorey and Dhaneshwar Ghura

July 5, 2011

\section{Key Issues}

Outlook: The fixed exchange regime will continue to anchor the region's macroeconomic policy. Supported by public investment and commodity exports, economic growth will remain robust, but below the sub-Saharan Africa (SSA) average. The foremost near-term risk is a decline in commodity prices, especially for oil. Also, rising global food and oil prices could lead to further inflation and possibly to demands for higher wages.

Ensuring fiscal and external sustainability: The union's real effective exchange rate, current account, and reserves are broadly consistent with external stability, but a downside risk over the longer term stems from noncompliance with rules for repatriating export receipts to the Bank of Central African States (BEAC). To ensure fiscal and external sustainability, public investment needs to be embedded in a realistic multiyear investment plan and the related annual budgets cast within a credible medium-term macroeconomic framework.

Fostering stronger non-oil growth: High rates of poverty will need to be addressed by promoting and diversifying non-oil growth. The priorities should be to refocus public investment on key infrastructure that will relieve major bottlenecks; pursue reforms in health and education sectors, which would enhance labor productivity and generate employment; and improve the business climate by strengthening governance and streamlining administrative procedures.

Reforming the financial sector: To safeguard financial sector stability, the prudential and regulatory framework should be reformed expeditiously and problems of systemically important weak banks resolved without delay. Institutional reforms to facilitate access to financial services should focus on improving the operations of land and commercial registries; streamlining the procedures for recording and enforcing guarantees; and strengthening creditor rights enforcement by improving the governance of the relevant courts.

\footnotetext{
${ }^{1}$ The staff team comprised Messrs. Akitoby (head), Keyfitz, Tapsoba, and Nxumalo (all AFR). Mr. Bah (OED) participated in the discussions. Mr. Kpodar, the IMF resident representative in Yaoundé, assisted the mission.
} 


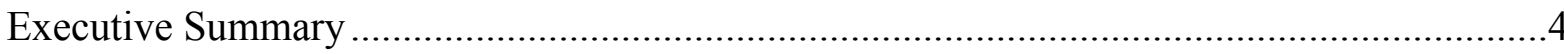

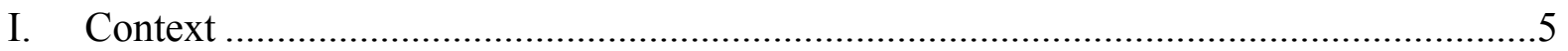

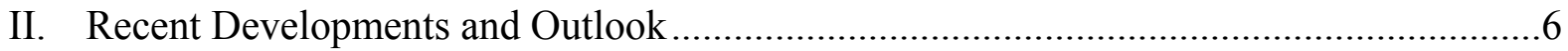

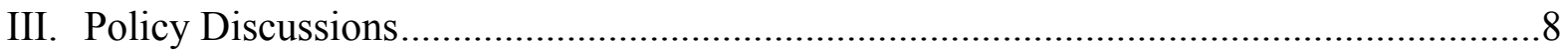

A. Ensuring Fiscal Sustainability and External Competitiveness............................10

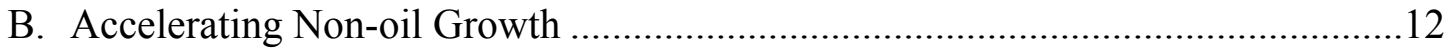

C. Reforming the Financial Sector .................................................................... 14

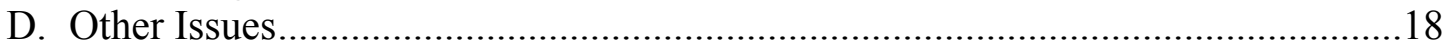

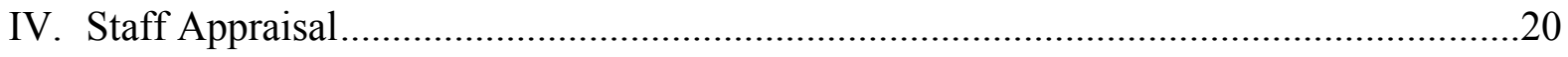

Tables

1. Millennium Development Goals - 2009 ...............................................................22

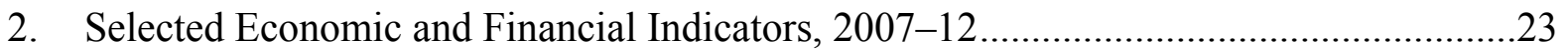

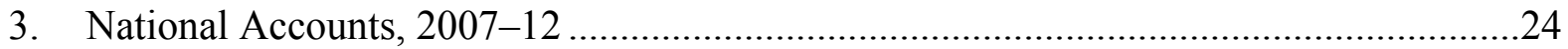

4. Nominal and Real Effective Exchange Rates, 2005-10 ..............................................25

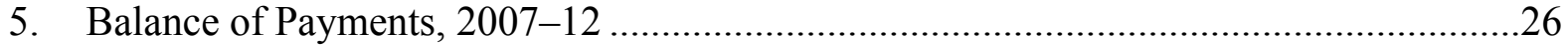

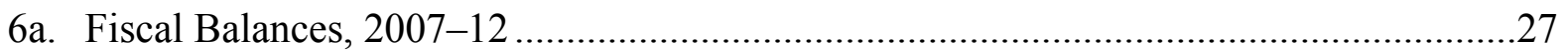

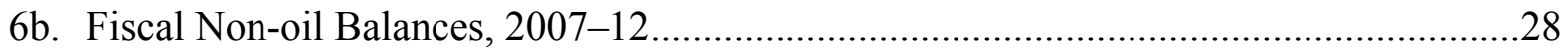

7. Compliance with Convergence Criteria, 2007-12 ….................................................29

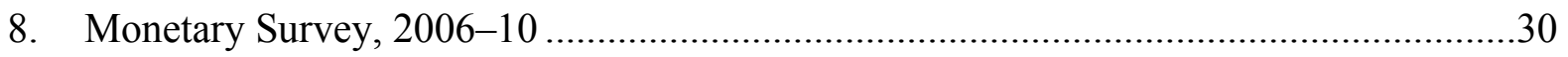

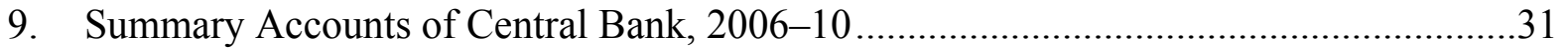

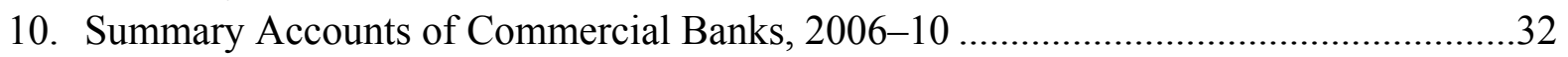

11. Summary Medium-Term Projections, 2007-16 …..................................................33

12. Relative Size of CEMAC Economies and Importance of Oil Sector, 2007-16 ..............34

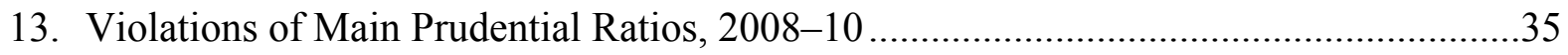

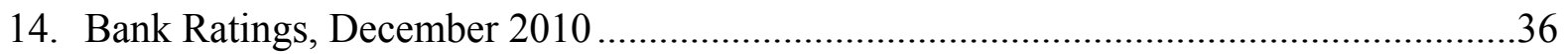

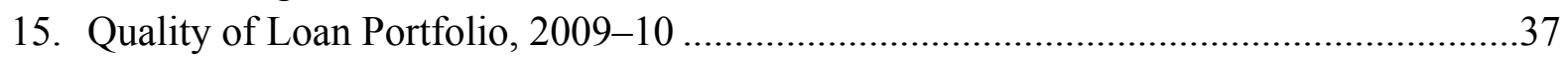

Figures

1. Growth and Development Challenges.................................................................. 7

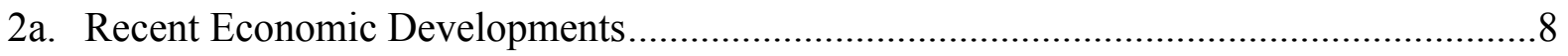

2b. Cross Country Comparison ....................................................................................

Appendixes

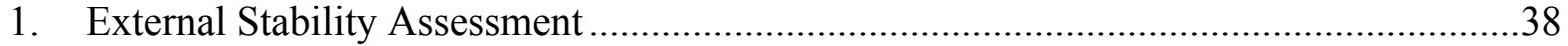

2. FSAP Recommendations — Status of Implementation ............................................41

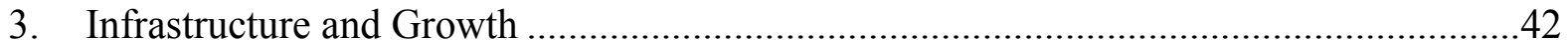

4. Determinants of Non-Oil Growth in the CFA-Zone Oil-Producing Countries ................46

5. Relations of CEMAC Member Countries and the Fund ..............................................56 


\section{List of Acronyms}

\begin{tabular}{|c|c|}
\hline AML/CFT & Anti Money Laundering and Combating the Financing of Terrorism \\
\hline BDEAC & Central African Development Bank \\
\hline BEAC & Bank of Central African States \\
\hline BRIC & Brazil, Russia, India, and China \\
\hline C.A.R. & Central African Republic \\
\hline CEMAC & Central African Economic and Monetary Community \\
\hline CET & common external tariff \\
\hline CFA & Coopération Financière en Afrique Centrale \\
\hline CFAF & CFA franc \\
\hline CIT & community integration tax \\
\hline COBAC & Central African Banking Commission \\
\hline CPIA & Country Policy and Institutional Assessment \\
\hline $\mathrm{ECF}$ & Extended Credit Facility \\
\hline ESAF & Enhanced Structural Adjustment Facility \\
\hline FSAP & Financial Sector Assessment Program \\
\hline GDP & gross domestic product \\
\hline ICT & information and communications technology \\
\hline IFS & International Financial Statistics \\
\hline IMF & International Monetary Fund \\
\hline LIC & low-income country \\
\hline MCM & Monetary and Capital Markets Department (IMF) \\
\hline MFD & Monetary and Financial Systems Department_-now MCM (IMF) \\
\hline MDG & Millennium Development Goal \\
\hline NOPD & non-oil primary deficit \\
\hline PIH & Permanent Income Hypothesis \\
\hline PRGF & Poverty Reduction and Growth Facility \\
\hline PRSP & Poverty Reduction Strategy Paper \\
\hline REER & real effective exchange rate \\
\hline REP & Regional Economic Program \\
\hline SDR & Special Drawing Right \\
\hline SME & small and medium-sized enterprises \\
\hline SMP & staff-monitored program \\
\hline SSA & sub-Saharan Africa \\
\hline STA & Statistics Department (IMF) \\
\hline UNDP & United Nations Development Program \\
\hline WAEMU & West African Economic and Monetary Union \\
\hline WEO & World Economic Outlook \\
\hline
\end{tabular}




\section{EXECUTIVE SUMMARY}

Background: The Central African Economic and Monetary Community (CEMAC) region is recovering from the global financial crisis, although economic growth has not returned to precrisis levels and continues to lag the sub-Saharan Africa (SSA) average. The region's inflation is higher than the West African Economic and Monetary Union (WAEMU) average. High commodity prices and healthy export demand improved the current account and fiscal balances. However, because of net accumulation of assets abroad by member countries, international reserves declined to about $4 \frac{1}{2}$ months of total imports or 100 percent of broad money in 2010 .

Outlook and risks: The fixed exchange regime will continue to anchor the region's macroeconomic policy. Supported by public investment and commodity exports, economic activity will remain robust, but below the SSA average. Inflation is projected to pick up because of rising food and fuel prices. The foremost near-term risk is a decline in commodity prices, especially for oil. Also, rising global food and oil prices could lead to further inflation and possibly to demands for higher wages.

Challenges: The overarching policy challenge is to address the widespread unemployment and poverty despite oil wealth. To lay the foundation for CEMAC's economic and social development, policy discussions focused on three key macroeconomic challenges (i) ensuring fiscal and external sustainability; (ii) fostering stronger non-oil growth; and (iii) reforming the financial sector.

Staff views: The union's real effective exchange rate, current account, and reserves are broadly consistent with external stability, but a downside risk over the longer term stems from noncompliance with rules for repatriating export receipts to the Bank of Central African States (BEAC). To ensure fiscal and external sustainability, public investment needs to be embedded in a realistic multiyear investment plan and the related annual budgets cast within a credible medium-term macroeconomic framework. To safeguard financial sector stability, the prudential and regulatory framework should be reformed expeditiously and problems of systemically important weak banks resolved without delay. High rates of poverty will need to be addressed by promoting and diversifying non-oil growth. The priorities should be to strengthen the quality of health and education, improve the business climate, build basic infrastructure, and facilitate access to financing for small and medium-sized enterprises (SMEs).

Authorities' views: The authorities agreed with the staff's recommendations. To safeguard external stability over the longer term, the issue of noncompliance with the rule of full repatriation of export receipts is currently under discussion. Financial sector stability is being strengthened through the reform of prudential and regulatory norms. However, the pace of the reform needs to be measured given the complexity of the transition and the need to ensure compliance with CEMAC's legal and institutional architecture. Regarding promoting non-oil growth, plans to improve the business environment are in place in most CEMAC countries. These plans focus on streamlining administrative procedures and improving infrastructure to help remove major supply bottlenecks. Initiatives to facilitate access to financial services include increasing transparency about lending costs, creating credit bureaus, improving disputes settlement mechanisms, and establishing a central registry of corporate balance sheets. 


\section{ConteXt}

1. The CEMAC has earned significant revenues from oil production in past decades, but faces substantial growth and development challenges (Figure 1). Five of the six CEMAC countries are oil producers; oil accounts for about 40 percent of regional GDP and 85 percent of total exports. Oil revenue, channeled through government spending, is the main driver of economic activity, but volatile oil prices and procyclical

\begin{tabular}{lccc}
\hline & $\begin{array}{c}\text { Life Expectancy } \\
\text { Index }\end{array}$ & Education Index & $\begin{array}{c}\text { Youth } \\
\text { Employment }\end{array}$ \\
\hline CEMAC & 0.51 & 0.41 & 47.0 \\
WAEMU & 0.54 & 0.28 & 55.6 \\
SSA & 0.55 & 0.50 & 49.0 \\
\hline
\end{tabular}

${ }^{1}$ Employment to population ratio, ages 15-24, total (\%).

Source: United Nations Development Programme, World Bank. fiscal policy have caused boom and bust cycles that have been exacerbated at times by rapidly rising and downwardly inflexible wages in a fixed exchange rate regime. Spending out of oil wealth has not led to more inclusive growth. Against the backdrop of high inequality, poverty and unemployment remain widespread, and it is unlikely the region will meet the Millennium Development Goals (MDGs) by 2015 (Table 1).

2. The overriding challenge for the CEMAC, therefore, is to seize the opportunity provided by oil wealth to increase substantially non-oil growth and achieve a significant and durable reduction in poverty. Ensuring productive public investment, improving the business climate to strengthen competitiveness and stimulate private investment, and increasing labor market flexibility can make important contributions to this effort. More fundamentally, high rates of poverty should be addressed by improving the quality of education and health spending and generating more employment opportunities in the non-oil sector.

3. Implementation of previous Fund policy advice has been mixed. The authorities have adopted the non-oil balance as a supplementary convergence criterion to assess long-run fiscal sustainability, but little progress has been made to embed capital budgets in a credible medium-term macroeconomic framework. Efforts have been made to improve liquidity management. In particular, government cash holdings have been largely centralized at the regional central bank, and statutory advances are being phased out. Work to establish a regional government securities market is well advanced. On safeguards concerns, the BEAC has made progress in implementing its action plan, but risks remain elevated in core functions and at the higher level of governance and oversight bodies. As regards the financial sector, some progress has been made in strengthening the financial stability framework, based on the 2006 Financial Sector Assessment Program (FSAP) report. However, the principal prudential regulations are still out of line with international best practices and poorly enforced. Regarding trade reforms, more needs to done to remove barriers to internal and external trade. 


\section{RECENT DEVELOPMENTS AND OUTLOOK}

4. The economic recovery is underway. Regional real GDP growth is recovering from the global financial crisis, although it has not returned to pre-crisis levels and continues to lag the SSA average (Figure 1). Moreover, the strength of the recovery varies across individual countries (Figure 2b). Although higher than the WAEMU average inflation, the region's inflation has been contained largely because higher international oil prices have not been passed through to domestic prices. Good harvests in Chad and the C.A.R. have also helped contain inflation. High commodity prices and healthy export demand improved the current account and fiscal balances. However, because of net accumulation of assets abroad by member countries, international reserves declined to $4 \frac{1}{2}$ months of total imports and 100 percent of broad money in 2010 .

5. There has been some progress in regional convergence (Table 7). All the CEMAC countries observed the criteria on public debt and nonaccumulation of arrears in 2010. However, only two of them met the requirement of a nonnegative basic fiscal balance. ${ }^{2}$ Moreover, Congo and Equatorial Guinea missed the inflation threshold. Overall, the total number of criteria violations declined from 9 in 2009 to 6 in 2010.

6. The regional economic outlook is generally positive. The fixed exchange regime will continue to anchor the region's macroeconomic policy. Supported by public investment and commodity exports, economic activity will remain robust, but inflation is projected to pick up because of rising food and fuel prices.

7. There are downside risks to this outlook. The foremost near-term risk is a decline in commodity prices, especially for oil, given the region's heavy dependence on commodity exports. Also, rising global food and oil prices could lead to inflation and possibly to demands for higher wages.

\section{Staff and the authorities agreed on the need to take policy measures to address} the impact of food and fuel price shocks. The first best policy response is to allow the passthrough of international prices to domestic prices, and then counteract the second-round effects of the food and fuel price shocks. The fixed exchange rate does not give the BEAC much room to conduct independent monetary policy. However, at the margin, the BEAC may need to tighten liquidity, should there be second-round effects of the food and fuel price shocks. Depending on the health of public finances and availability of external assistance, spending on social transfer schemes should be increased to cushion the impact of food and

\footnotetext{
${ }^{2}$ The basic fiscal balance is the overall fiscal balance net of grants and foreign-financed investment.
} 
Figure 1. CEMAC: Growth and Development Challenges, 2005-10
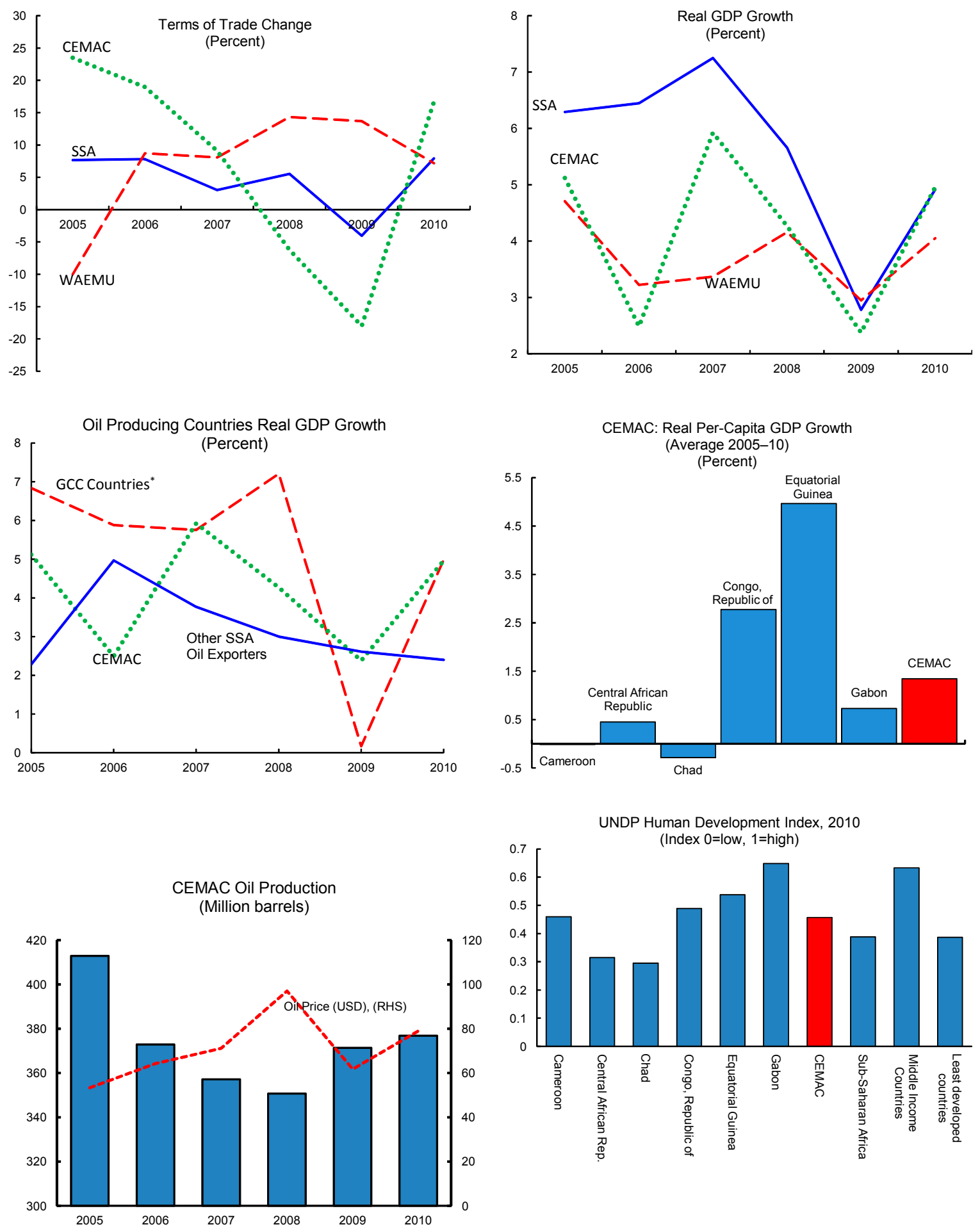

* Gulf Cooperation Council (GCC) countries Include Bahrain, Kuwait, Oman, Qatar, Saudi Arabia, and United Arab Emirates.

Sources: IMF, World Economic Outlook Database, and IMF Staff Estimates. 
Figure 2a. CEMAC: Recent Economic Developments
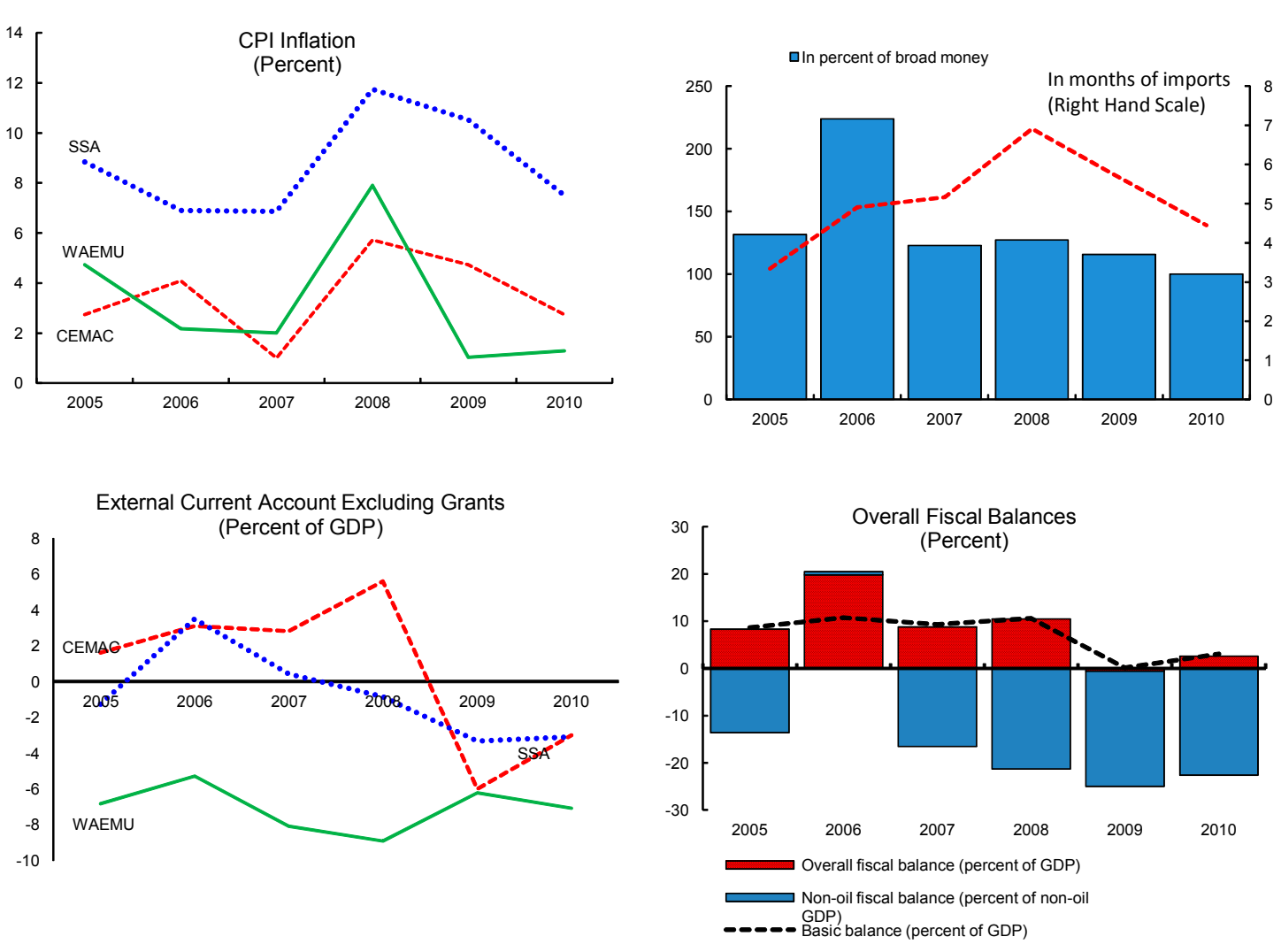

Sources: IMF, World Economic Outlook Database, and IMF Staff Estimates.

oil prices on the most vulnerable groups. Where identification of the neediest is not possible, other targeted relief could be considered. This might include a temporary lowering of import taxes on essential staple foods. Alternatively, prices of food items primarily consumed by the poorest households could be subsidized.

\section{Policy Discussions}

9. The overarching policy issue is widespread unemployment and poverty despite oil wealth. To establish enabling macroeconomic conditions, staff and the authorities agreed to focus policy discussions on three key macroeconomic challenges (i) ensuring fiscal and external sustainability; (ii) fostering stronger non-oil growth; and (iii) reforming the financial sector. 
Figure 2b. 2010 CEMAC Cross Country Comparison
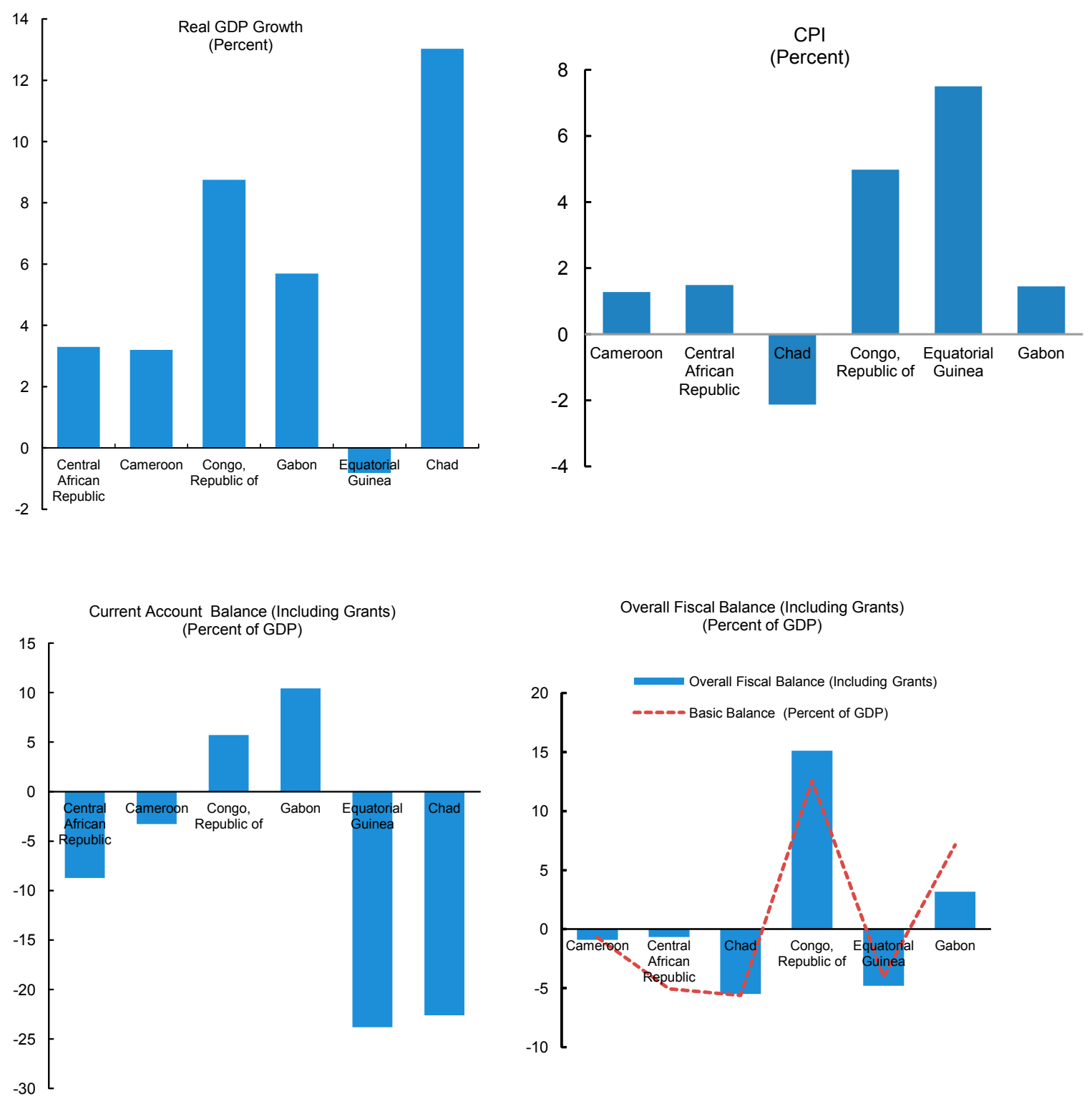

Source: IMF African Department Database. 


\section{A. Ensuring Fiscal Sustainability and External Competitiveness}

\section{Background}

10. The non-oil primary deficit (NOPD) of the CEMAC area has widened, driven by public investment. It is projected to move closer to the sustainable level of about 5 percent of non-oil GDP, derived from the Permanent Income Hypothesis (PIH) model, as investment tapers off in the medium term. However, for assessing the fiscal stance of a natural resource producer investing in domestic physical capital, the PIH model is only relevant as a long-term benchmark, because it does not distinguish between capital and current expenditure. ${ }^{3}$ For fiscal sustainability, public investment decisions need to be based on ensuring a rate of return at least equal to the rate on financial assets after allowing for differences in risk profiles of the two types of investment. The government's physical assets should yield, in risk-adjusted terms, at least the long-term real interest rate of investing in international financial assets (say, 2-3 percent) or an equivalent flow of social benefits, to warrant consideration. The quality of investment, therefore, is critical. The risk that the governments may not realize adequate returns through higher tax revenue or social benefits is significant in the CEMAC countries, because of poor governance and weak planning, implementation, monitoring, and maintenance of public investment projects (see Section B).

11. The fiscal position has important implications for external stability. With the fixed exchange regime, fiscal sustainability and external stability are intertwined. As domestic production is limited, swings in fiscal policy-mostly driven by public investment - tend to lead to an increase in imports rather than domestic demand. Methodologies for assessing real exchange rates in oil exporting countries indicate that the real effective exchange rate (REER) and the external position are broadly in line with fundamentals, although the range of uncertainty around the assessment is large (Appendix 1). However, at the same time, there is substantial evidence that nonprice structural factors are a major constraint on non-commodity competitiveness (see Section B).

12. The fixed exchange rate regime is secured in the near term by adequate reserves, with gross international reserves at $4 \frac{1}{2}$ months of total imports and 100 percent of broad

\footnotetext{
${ }^{3}$ See Collier Paul, Rick van der Ploeg, Michael Spence, and Anthony J. Venables, 2010, "Managing Resource Revenues in Developing Countries," IMF Staff Papers, Vol. 57, no. 1, pp. 84-118.
} 
money. Under current fiscal policies and the oil price outlook, gross international reserves are projected to stabilize at about 4 months of total imports by 2015. Reserve projections are sensitive to oil price projections, but analyses of reserves adequacy in the CEMAC show that coverage of about $4 \frac{1}{2}$ months of total imports would allow the region to withstand a large shock (two-standard-deviation shock to the trade balance). However, a risk to this outlook over the longer term is possible widespread noncompliance with the CEMAC rule requiring full repatriation of export receipts. Low interest rates on CFA franc denominated government deposits at the BEAC discourage compliance with the rule. In addition, recent safeguards concerns have weakened the member states' confidence in the BEAC, thus reducing the incentive for repatriating foreign currency receipts. The BEAC is making efforts, with assistance from the IMF, to address these issues.

\section{Staff policy advice}

A temporary deviation from the long-term NOPD derived from the PIH model is justifiable, taking into account the large investment needs in economic and social infrastructure. Given that the NOPD continues to be the long-term fiscal anchor, public investment needs to be embedded in a realistic multiyear investment plan and the related annual budgets cast within a medium-term macroeconomic framework consistent with fiscal and external sustainability. Moreover, public investment plans and execution should be scrutinized to ensure that they yield, in risk-adjusted terms, a real return at least equal to the long-term real interest rate on financial assets, as noted above. It will also be critical that public debt sustainability analyses be conducted regularly at the country level.

The external position and the REER are broadly consistent with external stability. However, the issue of noncompliance with full repatriation of export earnings could be referred to the CEMAC Council of Finance Ministers for discussion. All CEMAC countries should adhere to the rule of full repatriation of foreign exchange earnings.

Decisive implementation of safeguards measures and strengthening governance at the BEAC will help build up confidence in the central bank, thus reinforcing incentives for member states to entrust the BEAC with their export earnings.

In line with the IMF's technical assistance advice, the authorities should adopt a foreign reserves management strategy based on the desired international reserves to support the peg. The BEAC could invest excess foreign assets (above the desired level of international reserves) in investment portfolios, reflecting countries' investment horizon, return objectives, and risk profile. In parallel, the BEAC will need to strengthen its reserves management capacity, drawing on technical assistance.

\section{Authorities' views}

\section{The authorities agreed with staff's assessment of fiscal sustainability and} external competitiveness. They emphasized that the temporary surge in public investment to address development needs explains the short-term deviation from the long-run sustainable 
fiscal balance. CEMAC's NOPD will come down in the medium term once key projects are completed. Work is ongoing to anchor public investment in a credible medium-term fiscal strategy. For instance, in Congo, public investment was integrated into the 2010 budget process through the medium-term expenditure framework. In Gabon, a medium-term framework is being prepared to anchor the government's ambitious investment plan.

\section{The authorities recognized the need to address noncompliance with the CEMAC} rule requiring full repatriation of export receipts. At the CFA franc zone meeting in N'Djamena in April 2011, the finance ministers and governors took up the issue of centralizing foreign reserves in the central bank and ensuring compliance with the regulation requiring full repatriation of foreign exchange earnings. The authorities noted that continued progress on safeguard measures will bolster member states' incentives for repatriating foreign currency.

\section{B. Accelerating Non-oil Growth}

\section{Background}

15. CEMAC's non-oil sector growth has been disappointing. Although the zone has outperformed WAEMU, it has lagged its peers. Non-oil growth has also been on a downward trend, leading to fewer employment opportunities.

16. Available evidence suggests that CEMAC's non-oil sector is constrained by inadequate infrastructure services (Appendix 3). Infrastructure costs are very high because of insufficient and low-quality infrastructure and regulatory hurdles. To accelerate non-oil growth, oil-producing CEMAC countries have embarked on an ambitious investment

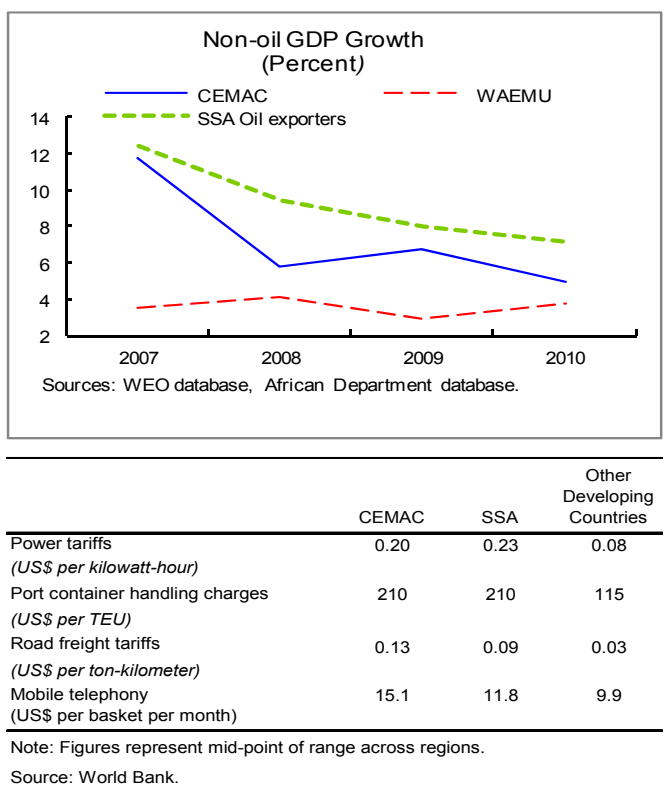
program. However, given weak administrative capacity, rapid scaling up of investment has a high likelihood of compromising spending quality. Staff analysis suggests that in the past public investment has had low returns and little impact on economic growth in the region (Appendix 4).

17. A poor business environment and low quality health and education services have also been constraints on growth. According to the World Bank's 2011 Doing 
Business Indicators, CEMAC's average ranking is lower than the SSA average (172 compared with 137 out of 183 countries). CEMAC countries ranked very low, with Chad and C.A.R. having the lowest ranking in the world, closely followed by Congo. ${ }^{4}$ Areas where they fared worst include starting a business, paying taxes, enforcing contracts, and trading across borders. Coupled with an unfriendly business environment, poor quality of health and education services has kept labor productivity low and explains the limited progress in raising human development indicators (see paragraph 1).

\section{Staff policy advice}

\section{The following reforms appear critical to sustaining non-oil growth:}

$>$ Refocus public investment on key infrastructure that will help relieve major supply bottlenecks (e.g., electricity, trade-enabling roads, dams, ports). The authorities may want to seek technical assistance, possibly from the World Bank, to strengthen the appraisal, selection, and monitoring of investment projects and the budgeting of operation and maintenance costs. Over the medium term, governments could explore the option of publicprivate partnerships to complement public investment, while containing the risk to public finances. ${ }^{5}$

Pursue reforms in health and education sectors that would enhance labor productivity, generate employment, and alleviate poverty over time.

Improve the business climate by strengthening governance and streamlining administrative procedures. Priority should be given to removing regulatory hurdles that thwart the infrastructure sector and to addressing areas where CEMAC countries fared worst in the World Bank's Doing Business survey.

\section{Authorities' views}

\section{The authorities emphasized their commitment to promoting non-oil sector} growth, key to supporting employment creation and a durable reduction in poverty. The 2007 regional conference on non-oil growth and economic diversification led to a clear consensus among key stakeholders (member states, private sector, civil society) on the priority measures needed to jump start growth in the non-oil sectors. The measures focused

\footnotetext{
${ }^{4}$ A similar conclusion can be drawn from other competitiveness indicators, such as the World Economic Forum's Global Competitiveness Index and the World Bank's CPIA rating for business regulatory environment.

${ }^{5}$ Lessons from the IMF cross-country pilot study can be drawn from Akitoby Bernardin and others, 2007 , "Public Investment and Private Public Partnerships," IMF Economics Issues, Vol. 40.
} 
on (i) preservation of macroeconomic stability; (ii) an outward-looking policy;

(iii) promotion of value-added activities based on the processing of commodities produced in the subregion (e.g., timber); (iv) enhancement of the government's role as regulator, facilitator, and supplier of basic infrastructure; and (v) improvement of the business environment and development of skilled labor.

20. The authorities recognized that public investment needed to be prioritized and refocused on growth-enabling infrastructure. At the regional level, the Regional Economic Program would make important contributions in this regard. At the national level, a number of countries have taken specific measures to strengthen public investment management. Notably, in Gabon, a national agency for major public works was set up, entrusted with the planning, management, and implementation of large public infrastructure projects. The U.S. engineering corporation, Bechtel, is providing the agency with technical expertise. A service agreement was also signed with the World Bank to enhance national capacities in this area. Similarly, in Cameroon, the authorities plan to establish a central unit for project feasibility studies and evaluation.

21. Plans to improve the business environment have been in place in most CEMAC countries since 2007. The focus is on streamlining administrative procedures and improving public-private dialogue. For instance, the Congolese authorities' plan to improve the business climate includes improving public-private dialogue, streamlining the tax system, and ensuring investment security. In Equatorial Guinea, work is underway to establish a one-stop shop for investment. In Cameroon, time to start a business has been reduced from 12 to 3 days, procedures for paying taxes simplified, and delays in the provision of construction permits shortened.

\section{Reforming the Financial Sector}

\section{Discussions focused on policy measures to strengthen financial stability and} broaden access to financial services. The 2006 FSAP continues to serve as the basis for policy dialogue on financial sector issues. Though some progress has been achieved in reforming the financial sector (Appendix 2), more remains to be done to safeguard financial stability and deepen the financial sector. 


\section{Strengthening financial sector stability and supervision}

\section{Background}

23. Some progress has been made in strengthening the financial stability framework since the 2006 FSAP report. The authorities have (i) harmonized and increased the minimum capital requirements for banks (CFAF 10 billion or US\$20 million);

(ii) strengthened corporate governance; and (iii) established a Financial Stability Committee to analyze financial sector vulnerabilities and advise on appropriate policy responses. The regional banking supervisor (COBAC) also introduced in 2009 a deposit insurance scheme, supervised by COBAC with the oversight of BEAC and banking sector representatives. The insurance deposit, funded by fees from financial institutions, will insure deposits up to CFAF 5 million.

\section{However, the principal prudential regulations (solvency, large exposures,} connected lending) are out of line with international best practices and poorly enforced, thus encouraging excessive credit concentration and exposing the banking system to credit risk. In addition, the protracted failure to resolve the financial problems of a systemically important regional banking group points to two weaknesses in the banking resolution framework and supervisory practices: (i) an inadequate legal framework for dealing with banking crises; and (ii) shortcomings in the cooperation of regional finance ministries. Effective supervision is further hampered by an acute shortage of qualified staff at COBAC.

\section{Staff policy advice}

Closely monitor bank compliance with the new regulation on minimum capital requirements and take the necessary steps in cases of noncompliance.

Perform regular stress tests to detect risks and vulnerabilities.

Finalize banking regulations to align them with international standards and best practices. In particular, the authorities should amend the regulations regarding (i) solvency ratios and risk diversification; (ii) lending to shareholders, partners, executives, and directors; (iii) market risks; and (iv) consolidated supervision. The CEMAC authorities should also adopt the regulation on banking crisis management as soon as possible.

The longer the current situation in financially weak banks persists, the higher could become the costs to governments, to the credibility of supervisory institutions, and reputational risks for CEMAC's financial sector. The authorities should (i) closely monitor liquidity conditions to avoid any suspension of payments by these banks; (ii) require full loss absorption by previous shareholders; and (iii) pursue maximum recovery of loans owed by related parties to minimize the financial costs to governments.

$>$ Increase COBAC's staffing significantly. To safeguard COBAC's ability to foster financial stability, staff emphasized the need to appoint qualified commissioners to COBAC. 


\section{Authorities' views}

\section{The authorities broadly shared staff recommendations and emphasized that}

$>$ It is important to implement reforms at an appropriate pace, given the complexity of the transition and the need to ensure that steps taken are aligned with CEMAC's legal and institutional architecture.

Although efforts had been made to increase COBAC staffing, the institution remained understaffed compared to the number of banks and microfinance establishments to be supervised. COBAC will be given priority in BEAC's 2011 hiring plan.

$>$ The regulations on the resolution of banking crises will be adopted by year-end and will enter into force on January 1, 2012. These regulations, which benefited from the IMF's technical assistance, are expected to (i) allow the authorities to take early intervention measures to resolve banking crises; (ii) define clearly the responsabilities of regional and national bodies and the scope of judicial review; and (iii) prohibit questionable shareholders from participating in a bank restructuring.

Regarding the performance of stress tests, a team was sent to the National Bank of Belgium for appropriate training.

\section{Financial sector deepening}

\section{Background}

25. Access to credit in the CEMAC region is among the lowest in Africa. The penetration rate is low (about 3 percent of the total population), and credit to the private sector is well below the average for sub-Saharan Africa. Structural factors that explain this situation are (i) high operating costs because of low population density, (ii) lack of credit information, and (iii) a weak institutional

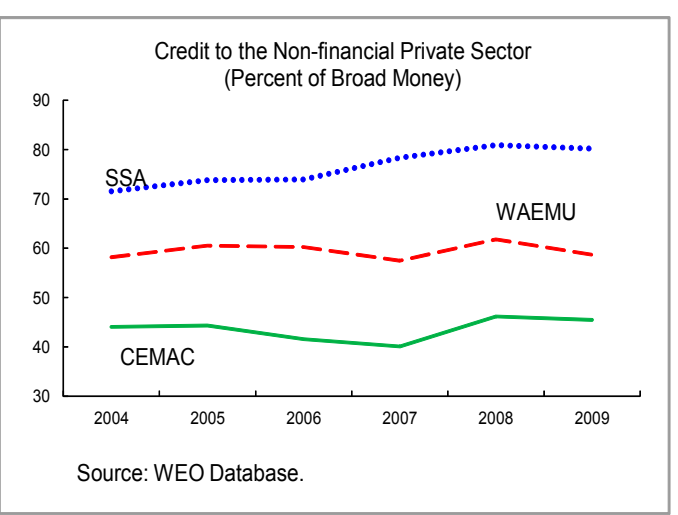
and legal framework. Given the limited role of microfinance institutions, most small and medium-sized enterprises (SMEs) find it difficult to obtain credit.

26. Delayed several times, a regional government securities market is expected to be launched soon. The technical prerequisites have been met. Notably, the regulatory and institutional framework is in place; all the agreements have been signed by the various stakeholders; and the Securities Settlement and Custody Unit has been established. 


\section{Staff policy advice}

27. Staff emphasized the need to improve the institutional framework. ${ }^{6}$ Institutional reforms should focus on (i) improving the operations of land and commercial registries, (ii) streamlining the procedures for recording and enforcing guarantees, and (iii) strengthening creditor rights enforcement by improving the governance of the relevant courts. The launch of a regional government securities market should be expedited to help manage excess liquidity and to mobilize and better distribute savings.

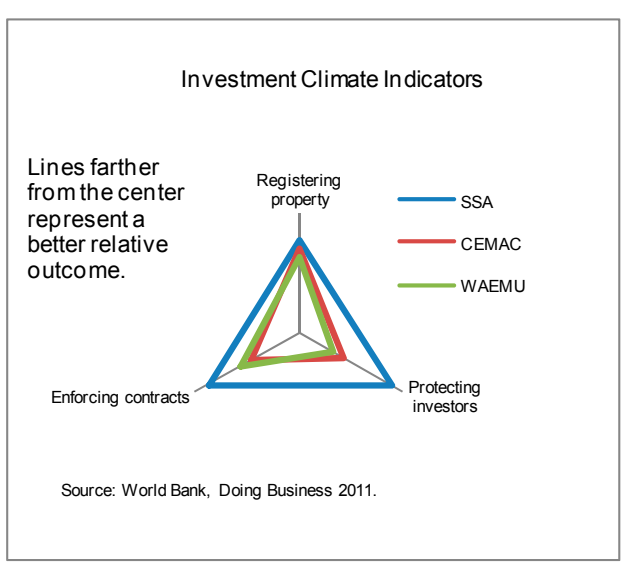

28. To improve SME and private household access to financial services, staff emphasized the need to create credit history centers on SMEs and urged the authorities to move ahead quickly with the implementation of microfinance strategies.

\section{Authorities' views}

29. The authorities agreed with the need to improve the institutional environment for the financial sector. Specific measures taken and actions in progress to deepen the financial sector include (i) regular publication of lending costs and related fees to promote banking transparency and competition, and also consumer protection; (ii) creation of a regional deposit insurance fund to protect small savers; (iii) creation of credit bureaus with World Bank technical assistance; and (iv) establishment of a credit rating agency and a central registry of corporate balance sheets to reduce information asymmetry in credit activities.

30. The institutional environment of microfinance has been strengthened.

Microfinance institutions have flourished since the introduction of the 2002 general regulation governing their activities. Their supervision was enhanced by the introduction in 2010 of a chart of accounts developed especially for them and the establishment of an IT system to collect financial data automatically.

\footnotetext{
${ }^{6}$ Akitoby, Bernardin (2010), “Seven Questions on How Institutions Shape Financial Markets,” IMF Research Bulletin, September.
} 


\section{Other Issues}

\section{Trade policy and regional integration}

31. CEMAC trade patterns have shifted toward emerging markets. Notably, trade with Brazil, Russia, India, and China (BRIC) has grown significantly, displacing the European Union. Meanwhile, at $1 \frac{1}{2}$ percent of total trade, intraregional trade is the lowest among regional trade groups in Africa.

\section{Trade barriers remain a}

significant obstacle. The common external tariff (CET) is higher than in most other African regions, yet some member states still impose additional surcharges and other fees. Regarding nontariff barriers, cross-country differences persist in (i) import classification and valuation;

(ii) exemptions rules; and (iii) implementation of rules of origins. Moreover, border procedures are cumbersome; and lack of coordination of customs administrations sometimes gives rise to double taxation of goods going to the hinterland. The lack of capacity and resources at the CEMAC Commission also hampers its ability to enforce trade reforms and community rules. Notably, the community integration tax (CIT), the commission's main source of financing, is not transferred in full by the member countries.

\section{Staff and the authorities agreed on the need to lower barriers to internal and} external trade. The priorities are to (i) expedite the intended lowering of the CET to bring it in line with the WAEMU CET, (ii) clarify the rules of origin, (iii) coordinate the customs administrations, and (iv) strengthen the capacity of the CEMAC Commission, especially through the timely transfer of the CIT revenues.

\section{Staff welcomed the Regional Economic Program (REP) and encouraged the} authorities to embed the related infrastructure projects in a credible medium-term investment plan. The REP intends to strengthen economic integration and position the region as an emerging market by 2025 . To implement the first phase (2011-15), an 
operational plan is being finalized. This plan describes the actions to be taken with regard to the strategic pillars of the REP, namely (i) shared vision; (ii) good governance and the business environment; (iii) economic infrastructure and land development; (iv) human capital; and (v) the common market and economic diversification. The REP's recognition of the importance of governance and transparency is particularly welcome. Specific measures proposed for the first phase of the program include reform of public procurement practices, increasing transparency in the management of natural resources, and strengthening governance in regional institutions and the judicial system.

\section{BEAC safeguards measures}

35. To address safeguards issues, the BEAC Board adopted an action plan aimed at improving governance and internal controls. Because of delays in the implementation of the action plan and additional safeguards concerns raised in the first special audit report, IMF disbursements to CEMAC countries were suspended after June 2010. Program reviews subsequently resumed, reflecting progress in meeting rolling benchmarks on safeguards measures. A recent safeguards monitoring mission has identified the need for further actions to address safeguards vulnerabilities in the accounting system (Syscobeac), the internal audit, and BEAC national directorates. The mission also noted that these actions would need to be supported by a strengthening of governance and oversight bodies. Progress will continue to be monitored on the basis of rolling benchmarks on safeguards measures (see Staff Note issued in June 2011 for the Board's information).

\section{Capacity building}

36. An IMF technical assistance program covering 2011-13 has been put in place to strengthen capacity at the BEAC and the COBAC (the regional banking supervisor). A resident advisor has already been posted to the BEAC and another one will soon be posted to COBAC. More broadly, the technical assistance program will cover the following fields: corporate governance of BEAC and COBAC; internal and external control systems; management, accounting, and budget supervision; reserves management; monetary policy; and the regional public debt market. The IMF is also providing technical support to the CEMAC Commission for the preparation of regional directives on public financial management. The main objectives are to (i) promote modernized, effective, and transparent public financial management in all member states; and (ii) enable comparability of public finance data for effective multilateral surveillance of national budgetary policies.

\section{Data quality}

37. While data provision is generally adequate for surveillance, staff analysis is hampered by shortcomings in data timeliness. Shortcomings are most evident in public finance, balance of payments, national accounts, and financial sector data. The authorities recognize 
the need to improve data collection and dissemination and are taking steps to strengthen economic and financial data, with technical assistance from the Fund.

\section{Staff APpraisal}

38. After being hit hard by the global economic crisis, the CEMAC region is recovering quickly. Near-term growth is projected to rise, supported by public investment and commodity exports. Inflation is forecast to pick up because of rising food and fuel prices. The foremost near-term risk is a decline in commodity prices.

\section{An appropriate policy mix is warranted to deal with the food and fuel price}

shocks. Liquidity may need to be tightened to counteract possible second-round effects of the shock, while spending is reallocated towards measures that mitigate the adverse impact on the most vulnerable groups.

40. High-quality public investment is vital to long-term growth, fiscal sustainability, and external competitiveness. Capital budgets should be anchored in a realistic multiyear investment plan and a credible medium-term fiscal strategy. Annual budgets need to be linked to longer-term policies and to making progress toward fiscal sustainability. In addition, public investment should yield, in risk-adjusted terms, a real return at least equal to the long-term real interest rate on financial assets.

41. Good governance and accountability are critical for ensuring the efficient use of public resources and obtaining the long-term growth dividend from ambitious public investment plans. Better public financial management is needed to improve the quality of spending and release resources for growth-enhancing spending and human development. Accelerating reforms to refocus public investment on key infrastructure and social projects and to strengthen the appraisal, selection, and monitoring of projects is crucial for ensuring that oil resources are spent productively. Stringent mechanisms should also be in place to ensure transparency and accountability in the management of oil wealth.

42. The union's real effective exchange rate, current account, and reserves are broadly consistent with external stability. A downside risk to the fixed exchange rate regime over the longer term stems from noncompliance with rules for repatriating export receipts to BEAC. Implementation of safeguards measures will help build confidence in the BEAC and strengthen incentives for country members to entrust the BEAC with their export earnings.

\section{The high rates of poverty need to be addressed by promoting and diversifying} non-oil growth. The priorities should be to build key infrastructure that will relieve major bottlenecks; pursue reforms in health and education sectors, which would enhance labor productivity and generate employment; and improve the business climate by strengthening governance and streamlining administrative procedures. Removing barriers to internal and 
external trade will also contribute to improving regional growth and alleviating poverty over time.

44. Efforts to reform the financial sector should be accelerated. Notably, the prudential and regulatory framework needs to be reformed expeditiously and rigorously enforced. The current situation of financially weak banks needs to be addressed urgently, including by closely monitoring their liquidity conditions and minimizing fiscal costs by requiring full loss absorption by previous shareholders and maximizing loan recovery from related parties. It is also essential to adopt the regulation on banking crisis management as soon as possible and to increase staff resources for COBAC. To increase access to financial services, priority should be given to improving the institutional and regulatory environment, in particular for SMEs.

45. The data provided to the IMF are generally adequate for surveillance. However, improvements are needed in balance of payments statistics and timeliness of fiscal, monetary, and financial data.

46. Staff proposes that regional discussions with the CEMAC authorities remain on the standard 12-month consultation cycle. 
Table 1. CEMAC: Millenium Development Goals-2009

\begin{tabular}{|c|c|c|c|c|c|}
\hline & \multicolumn{3}{|c|}{1990} & \multicolumn{2}{|c|}{2009} \\
\hline & CEMAC & & SSA & CEMAC & SSA \\
\hline \multicolumn{6}{|l|}{ Goal 1: Eradicate extreme poverty and hunger } \\
\hline Employment to population ratio, ages $15-24$, total (\%) & 49 & & 50 & 47 & 49 \\
\hline GDP per person employed (constant 1990 PPP \$) & $\ldots$ & & 2,493 & $\ldots$ & $\ldots$ \\
\hline Income share held by lowest $20 \%$ & $\ldots$ & .. & & $\ldots$ & .. \\
\hline Poverty gap at $\$ 1.25$ a day (PPP) $(\%)$ & $\ldots$ &.. & & $\ldots$ & .. \\
\hline Poverty headcount ratio at $\$ 1.25$ a day (PPP) (\% of population) & $\ldots$ & & 58 & $\ldots$ & 51 \\
\hline Vulnerable employment, total (\% of total employment) & $\ldots$ &.. & & $\ldots$ & .. \\
\hline \multicolumn{6}{|l|}{ Goal 2: Achieve universal primary education } \\
\hline Literacy rate, youth female (\% of females ages $15-24)$ & 35 & & 58 & 74 & 67 \\
\hline Literacy rate, youth male (\% of males ages $15-24)$ & 63 & & 73 & 82 & 77 \\
\hline \multicolumn{6}{|l|}{ Goal 3: Promote gender equality and empower women } \\
\hline Proportion of seats held by women in national parliaments (\%) & 12 & .. & & 11 & 18 \\
\hline Ratio of female to male primary enrollment (\%) & 77 & & 84 & 83 & 91 \\
\hline Ratio of female to male secondary enrollment (\%) & 52 & & 76 & 61 & 79 \\
\hline Ratio of female to male tertiary enrollment (\%) & 18 & .. & & 43 & 68 \\
\hline Share of women employed in the nonagricultural sector (\% of total nonagricultural employment) & .. &.. & & & \\
\hline \multicolumn{6}{|l|}{ Goal 4: Reduce child mortality } \\
\hline Immunization, measles (\% of children ages $12-23$ months) & 68 & & 57 & 57 & 68 \\
\hline Mortality rate, infant (per 1,000 live births) & 97 & & 109 & 92 & 81 \\
\hline Mortality rate, under-5 (per 1,000$)$ & 153 & & 181 & 146 & 130 \\
\hline \multicolumn{6}{|l|}{ Goal 5: Improve maternal health } \\
\hline Adolescent fertility rate (births per 1,000 women ages $15-19)$ &.. & .. & & 119 & 116 \\
\hline Condom use, population ages $15-24$, female ( $\%$ of females ages $15-24)$ & .. & .. & & 14 & 19 \\
\hline Condom use, population ages $15-24$, male (\% of males ages $15-24)$ & .. &.. & & 35 & 36 \\
\hline Incidence of tuberculosis (per 100,000 people) & 126 & & 180 & 298 & 350 \\
\hline Prevalence of HIV, female (\% ages $15-24)$ &.. & .. & & 4 & 3 \\
\hline Prevalence of HIV, male (\% ages $15-24)$ & .. & .. & & 1 & 1 \\
\hline Prevalence of HIV, total (\% of population ages $15-49$ ) & 2 & & 2 & 5 & 5 \\
\hline Tuberculosis case detection rate (all forms) & 51 & & 45 & 60 & 46 \\
\hline \multicolumn{6}{|l|}{ Goal 7: Ensure environmental sustainability } \\
\hline CO2 emissions (kg per PPP \$ of GDP) & 0 & & 1 & 0 & 0 \\
\hline CO2 emissions (metric tons per capita) & 1 & & 1 & 1 & 1 \\
\hline Forest area (\% of land area) & 53 & & 29 & 49 & 26 \\
\hline Improved sanitation facilities (\% of population with access) & 21 & & 27 & 31 & 31 \\
\hline Improved water source (\% of population with access) & 49 & & 49 & 70 & 60 \\
\hline Marine protected areas ( $\%$ of total surface area) & .. &.. & & 2 & 0 \\
\hline Terrestrial protected areas ( $\%$ of total surface area) & .. & .. & & 14 & 12 \\
\hline \multicolumn{6}{|l|}{ Goal 8: Develop a global partnership for development } \\
\hline Net ODA received per capita (current US\$) & 94 & & 35 & 58 & 49 \\
\hline Debt service (PPG and IMF only, \% of exports, excluding workers' remittances) & &.. & & & 2 \\
\hline Internet users (per 100 people) & 0 & & 0 & 3 & 7 \\
\hline Mobile cellular subscriptions (per 100 people) & 0 & & 0 & 41 & 33 \\
\hline Telephone lines (per 100 people) & 1 & & 1 & 1 & 2 \\
\hline \multicolumn{6}{|l|}{ Other } \\
\hline
\end{tabular}

Source: World Development Indicators. 
Table 2. CEMAC: Selected Economic and Financial Indicators, 2007-12

\begin{tabular}{|c|c|c|c|c|c|c|}
\hline & 2007 & 2008 & 2009 & $\begin{array}{l}2010 \\
\text { Est. }\end{array}$ & $\begin{array}{l}2011 \\
\text { Proj. }\end{array}$ & $\begin{array}{l}2012 \\
\text { Proj. }\end{array}$ \\
\hline & \multicolumn{6}{|c|}{ (Annual percent change) } \\
\hline \multicolumn{7}{|l|}{ National income and prices } \\
\hline GDP at constant prices & 5.9 & 4.3 & 2.4 & 5.0 & 5.2 & 4.2 \\
\hline Oil GDP & 3.7 & 3.5 & -4.9 & -2.4 & 1.7 & 3.8 \\
\hline Non-oil GDP & 11.8 & 5.9 & 6.2 & 5.2 & 6.8 & 5.4 \\
\hline Consumer prices (average) ${ }^{1}$ & 1.0 & 5.7 & 4.7 & 2.7 & 4.1 & 3.9 \\
\hline Consumer prices (end of period) ${ }^{1}$ & 3.0 & 7.1 & 2.9 & 2.9 & 3.5 & 3.0 \\
\hline Nominal effective exchange rate ${ }^{1}$ & 3.1 & 3.2 & -0.1 & -4.1 & .. & .. \\
\hline \multirow[t]{2}{*}{ Real effective exchange rate ${ }^{1}$} & 0.9 & 5.1 & 2.9 & -3.9 & .. & .. \\
\hline & \multicolumn{6}{|c|}{$\begin{array}{l}\text { (Annual changes in percent of beginning- } \\
\text { of-period broad money) }\end{array}$} \\
\hline \multicolumn{7}{|l|}{ Money and credit } \\
\hline Net foreign assets & 35.6 & 30.3 & -13.5 & -13.2 & $\ldots$ & $\ldots$ \\
\hline Net domestic assets & -23.3 & -12.3 & 19.5 & 28.0 & $\ldots$ & $\ldots$ \\
\hline \multirow[t]{2}{*}{ Broad money } & 13.9 & 18.4 & 12.2 & 18.4 & $\ldots$ & $\ldots$ \\
\hline & \multicolumn{6}{|c|}{ (In percent of GDP, unless otherwise indicated) } \\
\hline Gross national savings & 24.2 & 26.9 & 18.5 & 20.0 & 29.3 & 28.3 \\
\hline Gross domestic investment & 21.5 & 19.8 & 24.7 & 25.6 & 25.5 & 26.1 \\
\hline Of which public & 8.0 & 8.7 & 13.6 & 11.3 & 12.0 & 12.4 \\
\hline \multicolumn{7}{|l|}{ Government financial operations } \\
\hline Total revenue, excluding grants & 27.8 & 30.6 & 26.0 & 25.5 & 29.3 & 29.4 \\
\hline Government expenditure & 19.5 & 20.3 & 26.9 & 23.3 & 23.1 & 23.8 \\
\hline Primary basic fiscal balance ${ }^{2}$ & 10.4 & 11.7 & 0.9 & 3.6 & 9.3 & 8.9 \\
\hline Basic fiscal balance $^{3}$ & 9.3 & 10.7 & 0.1 & 3.0 & 8.4 & 8.3 \\
\hline Overall fiscal balance, excluding grants & 8.4 & 10.3 & -0.9 & 2.2 & 6.2 & 5.5 \\
\hline Non-oil overall fiscal balance, excluding grants (percent of Non-oil GDP) & -17.6 & -22.4 & -25.5 & -23.4 & -23.9 & -22.8 \\
\hline Overall fiscal balance, including grants & 8.7 & 10.4 & -0.6 & 2.5 & 7.6 & 7.5 \\
\hline \multicolumn{7}{|l|}{ External sector } \\
\hline Exports of goods and nonfactor services & 55.7 & 57.2 & 47.3 & 53.0 & 55.8 & 53.7 \\
\hline Imports of goods and nonfactor services & 35.2 & 35.2 & 42.5 & 41.8 & 40.5 & 38.3 \\
\hline Balance on goods and nonfactor services & 20.5 & 22.0 & 4.8 & 11.1 & 15.2 & 15.5 \\
\hline Current account, including grants & 4.7 & 7.2 & -5.5 & -2.8 & 0.7 & 2.0 \\
\hline External Public debt & 18.7 & 11.5 & 10.3 & 6.0 & 5.9 & 6.2 \\
\hline \multicolumn{7}{|l|}{ Gross official reserves (end of period) } \\
\hline In millions of U.S. dollars & 11,937 & 15,662 & 14,354 & 13,658 & .. & .. \\
\hline In months of imports of goods and services & 5.2 & 6.9 & 5.7 & 4.5 & .. & .. \\
\hline In percent of broad money & 120.3 & 124.5 & 112.4 & 101.1 & .. & .. \\
\hline \multicolumn{7}{|l|}{ Memorandum items: } \\
\hline Nominal GDP (in billions of CFA francs) & 29535.5 & 35294.0 & 30220.8 & 35934.9 & 41658.4 & 43503.3 \\
\hline CFA francs per U.S. dollar, average & 479.3 & 447.8 & 472.2 & 495.3 & 479.2 & 481.6 \\
\hline Oil prices (in US\$ per barrel) & 71.1 & 97.0 & 61.8 & 79.0 & 107.2 & 108.0 \\
\hline
\end{tabular}

Sources: IMF, World Economic Outlook database; and staff estimates and projections.

${ }^{1}$ Using as weights the shares of member countries in CEMAC's GDP in purchasing power parity US\$

${ }^{2}$ Excluding grants and foreign-financed investment and interest payments.

${ }^{3}$ Excluding grants and foreign-financed investment. 
Table 3. CEMAC: National Accounts, 2007-12

\begin{tabular}{|c|c|c|c|c|c|c|}
\hline & 2007 & 2008 & 2009 & $\begin{array}{r}2010 \\
\text { Est. }\end{array}$ & $\begin{array}{l}2011 \\
\text { Proj. }\end{array}$ & $\begin{array}{c}2012 \\
\text { Proj. }\end{array}$ \\
\hline & \multicolumn{6}{|c|}{ (Annual percent change) } \\
\hline \multicolumn{7}{|l|}{ Real GDP } \\
\hline Cameroon & 3.4 & 2.6 & 2.0 & 3.2 & 3.8 & 4.5 \\
\hline Central African Republic & 3.7 & 2.0 & 1.7 & 3.3 & 4.1 & 5.0 \\
\hline Chad & 0.2 & 1.7 & -1.2 & 13.0 & 4.7 & 3.9 \\
\hline Congo, Republic of & -1.6 & 5.6 & 7.5 & 8.8 & 6.3 & 5.3 \\
\hline Equatorial Guinea & 21.4 & 10.7 & 5.7 & -0.8 & 7.2 & 4.0 \\
\hline Gabon & 5.6 & 2.3 & -1.4 & 5.7 & 5.6 & 3.3 \\
\hline CEMAC & 5.9 & 4.3 & 2.4 & 5.0 & 5.2 & 4.2 \\
\hline \multicolumn{7}{|l|}{ Nominal GDP } \\
\hline Cameroon & 4.3 & 8.5 & -1.5 & 6.3 & 7.9 & 6.9 \\
\hline Central African Republic & 5.6 & 9.2 & 5.3 & 6.6 & 7.6 & 8.3 \\
\hline Chad & 2.0 & 11.4 & -10.6 & 26.5 & 6.5 & -2.0 \\
\hline Congo, Republic of & -1.1 & 32.0 & -14.3 & 30.3 & 22.7 & 3.3 \\
\hline Equatorial Guinea & 20.0 & 36.9 & -30.0 & 24.2 & 25.7 & 6.0 \\
\hline Gabon & 11.1 & 17.3 & -20.6 & 25.9 & 20.2 & 3.1 \\
\hline CEMAC & 7.4 & 19.5 & -14.4 & 18.9 & 15.9 & 4.4 \\
\hline \multicolumn{7}{|l|}{ Real non-oil GDP } \\
\hline Cameroon & 4.0 & 3.1 & 2.9 & 4.0 & 4.4 & 4.0 \\
\hline Central African Republic & 3.7 & 2.0 & 1.7 & 3.3 & 4.1 & 5.0 \\
\hline Chad & 3.1 & 3.0 & 0.1 & 15.9 & 5.3 & 5.0 \\
\hline Congo, Republic of & 6.6 & 5.4 & 3.9 & 6.5 & 7.4 & 7.8 \\
\hline Equatorial Guinea & 47.2 & 18.1 & 27.6 & 5.3 & 12.8 & 5.0 \\
\hline Gabon & 6.2 & 3.4 & -0.5 & 6.2 & 6.7 & 4.4 \\
\hline CEMAC & 11.8 & 5.9 & 6.2 & 5.2 & 6.8 & 5.4 \\
\hline \multicolumn{7}{|c|}{ Consumer price inflation (average) } \\
\hline Cameroon & 1.1 & 5.3 & 3.0 & 1.3 & 2.6 & 2.5 \\
\hline Central African Republic & 0.9 & 9.3 & 3.5 & 1.5 & 3.1 & 2.8 \\
\hline Chad & -7.4 & 8.3 & 10.1 & -2.1 & -2.0 & -2.0 \\
\hline Congo, Republic of & 2.6 & 6.0 & 4.3 & 5.0 & 5.9 & 5.2 \\
\hline Equatorial Guinea & 2.8 & 4.3 & 7.2 & 7.5 & 7.3 & 7.0 \\
\hline Gabon & 5.0 & 5.3 & 1.9 & 1.4 & 2.3 & 3.4 \\
\hline CEMAC & 1.0 & 5.7 & 4.7 & 2.7 & 4.1 & 3.9 \\
\hline Gross national saving & \multicolumn{6}{|c|}{ (Percent of GDP) } \\
\hline Cameroon & 16.4 & 16.3 & 12.9 & 13.3 & 13.9 & 14.8 \\
\hline Central African Republic & 4.5 & 2.3 & 5.3 & 5.1 & 4.9 & 6.9 \\
\hline Chad & 26.6 & 15.9 & -25.8 & -31.4 & -45.6 & 17.6 \\
\hline Congo, Republic of & 14.0 & 19.6 & 13.6 & 27.5 & 32.3 & 37.1 \\
\hline Equatorial Guinea & 39.6 & 34.9 & 31.0 & 24.4 & 25.6 & 26.3 \\
\hline Gabon & 41.9 & 45.6 & 33.1 & 37.1 & 41.6 & 40.3 \\
\hline CEMAC & 24.2 & 26.9 & 18.5 & 20.0 & 29.3 & 28.3 \\
\hline Gross domestic investment & \multicolumn{6}{|c|}{ (Percent of GDP) } \\
\hline Cameroon & 15.0 & 17.5 & 16.6 & 16.7 & 18.3 & 18.6 \\
\hline Central African Republic & 10.7 & 12.7 & 13.2 & 13.9 & 13.5 & 14.8 \\
\hline Chad & 26.6 & 24.8 & 36.9 & 37.9 & 27.1 & 43.2 \\
\hline Congo, Republic of & 21.9 & 18.4 & 22.5 & 21.8 & 21.8 & 23.1 \\
\hline Equatorial Guinea & 35.3 & 25.9 & 48.1 & 48.3 & 35.8 & 36.2 \\
\hline Gabon & 24.7 & 21.6 & 27.0 & 26.7 & 25.9 & 26.6 \\
\hline CEMAC & 21.5 & 19.8 & 24.7 & 25.6 & 25.5 & 26.1 \\
\hline
\end{tabular}

Sources: IMF, World Economic Outlook database; and staff estimates and projections. 
Table 4. CEMAC: Nominal and Real Effective Exchange Rates, 2005-10

\begin{tabular}{|c|c|c|c|c|c|c|}
\hline & 2005 & 2006 & 2007 & 2008 & 2009 & 2010 \\
\hline \multicolumn{7}{|c|}{ Nominal effective exchange rate } \\
\hline & \multicolumn{6}{|c|}{ Index $(2005=100)$} \\
\hline Cameroon & 100.0 & 99.5 & 102.6 & 105.1 & 106.1 & 101.3 \\
\hline Central African Republic & 100.0 & 99.9 & 102.9 & 105.5 & 104.7 & 100.3 \\
\hline Chad & 100.0 & 100.0 & 102.5 & 105.4 & 106.3 & 103.2 \\
\hline Congo, Republic of & 100.0 & 99.9 & 102.6 & 106.4 & 105.6 & 100.3 \\
\hline Equatorial Guinea & 100.0 & 99.7 & 104.3 & 110.4 & 109.0 & 104.1 \\
\hline Gabon & 100.0 & 100.0 & 102.1 & 104.1 & 103.3 & 99.8 \\
\hline \multirow[t]{2}{*}{ CEMAC $^{1}$} & 100.0 & 99.8 & 102.8 & 106.1 & 106.0 & 101.6 \\
\hline & \multicolumn{6}{|c|}{ (Annual percent change) } \\
\hline Cameroon & -1.7 & -0.5 & 3.1 & 2.5 & 0.9 & -4.4 \\
\hline Central African Republic & -1.4 & -0.1 & 3.0 & 2.5 & -0.8 & -4.2 \\
\hline Chad & 0.0 & 0.0 & 2.5 & 2.8 & 0.9 & -2.9 \\
\hline Congo, Republic of & -1.2 & -0.1 & 2.7 & 3.7 & -0.8 & -5.0 \\
\hline Equatorial Guinea & -0.2 & -0.3 & 4.6 & 5.8 & -1.3 & -4.5 \\
\hline Gabon & -0.6 & 0.0 & 2.2 & 1.9 & -0.7 & -3.4 \\
\hline CEMAC $^{1}$ & -0.9 & -0.2 & 3.1 & 3.2 & -0.1 & -4.1 \\
\hline \multicolumn{7}{|c|}{ Real effective exchange rate } \\
\hline & \multicolumn{6}{|c|}{ Index $(2005=100)$} \\
\hline Cameroon & 100.0 & 101.5 & 102.5 & 105.6 & 108.1 & 101.3 \\
\hline Central African Republic & 100.0 & 104.0 & 105.3 & 113.4 & 115.8 & 110.5 \\
\hline Chad & 100.0 & 104.8 & 95.0 & 102.6 & 112.5 & 104.1 \\
\hline Congo, Republic of & 100.0 & 103.5 & 105.6 & 112.0 & 116.0 & 114.2 \\
\hline Equatorial Guinea & 100.0 & 101.5 & 106.4 & 115.5 & 118.1 & 121.2 \\
\hline Gabon & 100.0 & 96.4 & 101.0 & 104.5 & 105.3 & 97.9 \\
\hline \multirow[t]{2}{*}{ CEMAC $^{1}$} & 100.0 & 101.4 & 102.0 & 107.2 & 110.3 & 106.0 \\
\hline & \multicolumn{6}{|c|}{ (Annual percent change) } \\
\hline Cameroon & -2.6 & 1.5 & 1.0 & 3.0 & 2.2 & -6.3 \\
\hline Central African Republic & -0.8 & 4.0 & 1.2 & 7.7 & 2.0 & -4.7 \\
\hline Chad & 4.9 & 4.8 & -9.4 & 8.0 & 9.3 & -7.5 \\
\hline Congo, Republic of & -0.7 & 3.5 & 1.8 & 4.8 & 2.2 & -2.7 \\
\hline Equatorial Guinea & 2.6 & 1.5 & 4.9 & 8.6 & 2.2 & 2.6 \\
\hline Gabon & 1.0 & -3.6 & 4.7 & 3.5 & 0.8 & -3.8 \\
\hline CEMAC $^{1}$ & 0.3 & 1.4 & 0.9 & 5.1 & 2.9 & -3.9 \\
\hline
\end{tabular}

Sources: IMF, Information Notice System; and staff estimates.

${ }^{1}$ CEMAC data are weighted by GDP in purchasing power parity US\$. 
Table 5. CEMAC: Balance of Payments, 2007-12

\begin{tabular}{|c|c|c|c|c|c|c|}
\hline & 2007 & 2008 & 2009 & $\begin{array}{r}2010 \\
\text { Est. }\end{array}$ & $\begin{array}{l}2011 \\
\text { Proj. }\end{array}$ & $\begin{array}{c}2012 \\
\text { Proj. }\end{array}$ \\
\hline & \multicolumn{6}{|c|}{ (Billion CFAF) } \\
\hline Balance on current account & 1,381 & 2,514 & $-1,671$ & $-1,091$ & 526 & 1,135 \\
\hline Balance on goods and services & 6,068 & 7,750 & 1,446 & 4,003 & 6,614 & 7,063 \\
\hline Exports of goods & 15,406 & 19,043 & 13,063 & 17,726 & 22,714 & 22,958 \\
\hline Exports of services & 1,058 & 1,137 & 1,227 & 1,306 & 1,499 & 1,580 \\
\hline Imports of goods & $-6,004$ & $-7,517$ & $-8,021$ & $-9,538$ & $-11,294$ & $-11,142$ \\
\hline Imports of services & $-4,249$ & $-4,912$ & $-4,823$ & $-5,492$ & $-6,304$ & $-6,334$ \\
\hline Income, net & $-5,102$ & $-5,622$ & $-3,520$ & $-5,404$ & $-6,379$ & $-6,295$ \\
\hline Income credits & 110 & 159 & 201 & 222 & 253 & 376 \\
\hline Income debits & $-5,851$ & $-5,780$ & $-3,758$ & $-5,592$ & $-6,608$ & $-6,626$ \\
\hline \multicolumn{7}{|l|}{ Of which } \\
\hline Investment income, debit & $-1,029$ & $-1,154$ & -827 & $-1,138$ & $-1,540$ & $-1,610$ \\
\hline Interest paid on public debt & -129 & -118 & -69 & -62 & -68 & -85 \\
\hline Interest paid on nonpublic debt & -82 & -68 & -22 & -12 & -12 & -20 \\
\hline Current transfers, net & 415 & 385 & 403 & 311 & 290 & 368 \\
\hline Private current transfers, net & 264 & 214 & 268 & 216 & 147 & 157 \\
\hline Official current transfers, net & 151 & 171 & 135 & 95 & 144 & 211 \\
\hline Balance on capital and financial account & $-1,276$ & $-1,955$ & 640 & 706 & -526 & $-1,135$ \\
\hline Balance on capital account (incl. capital transfers) & 126 & 318 & 500 & 1,405 & 176 & 259 \\
\hline Balance on financial account (incl. reserves) & $-1,402$ & $-2,273$ & 140 & -699 & -702 & $-1,394$ \\
\hline Direct investment, net & 2,313 & 1,625 & 2,278 & 2,986 & 3,270 & 2,949 \\
\hline Portfolio investment, net & 449 & 51 & 2 & 2 & 0 & 0 \\
\hline Other investment, net & $-3,090$ & $-2,657$ & $-2,376$ & $-3,700$ & 215 & -780 \\
\hline Reserve assets (accumulation -) & $-1,073$ & $-1,293$ & 236 & 13 & $-4,188$ & $-3,563$ \\
\hline Errors and omissions, net & -105 & -559 & 1,031 & 385 & 0 & 0 \\
\hline \multicolumn{7}{|l|}{ Memorandum item: } \\
\hline Nominal GDP & 29,535 & 35,294 & 30,221 & 35,935 & 41658.36 & 43503.30 \\
\hline \multicolumn{7}{|l|}{ Gross official reserves (end of period) } \\
\hline In billion CFAF & 5721 & 7014 & 6778 & 6764 & $\ldots$ & $\ldots$ \\
\hline In millions of U.S. dollars & 11,937 & 15,662 & 14,354 & 13,658 & $\ldots$ & $\ldots$ \\
\hline In months of imports of goods and services & 5.2 & 6.9 & 5.7 & 4.5 & $\ldots$ & $\ldots$ \\
\hline
\end{tabular}

Sources: IMF, World Economic Outlook database; and staff estimates and projections. 
Table 6a. CEMAC: Fiscal Balances, 2007-12

(In percent of GDP)

\begin{tabular}{|c|c|c|c|c|c|c|}
\hline & 2007 & 2008 & 2009 & $\begin{array}{r}2010 \\
\text { Est. }\end{array}$ & $\begin{array}{l}2011 \\
\text { Proj. }\end{array}$ & $\begin{array}{r}2012 \\
\text { Proj. }\end{array}$ \\
\hline \multicolumn{7}{|c|}{ Overall fiscal balance (excluding grants) } \\
\hline Cameroon & 3.3 & 1.5 & -0.9 & -1.7 & -1.9 & -1.0 \\
\hline Central African Republic & -2.9 & -5.8 & -5.3 & -6.1 & -4.1 & -4.4 \\
\hline Chad & 1.7 & 3.0 & -13.4 & -7.1 & 4.5 & 2.2 \\
\hline Congo, Republic of & 9.1 & 22.8 & 4.5 & 15.1 & 29.8 & 30.0 \\
\hline Equatorial Guinea & 19.3 & 15.4 & -8.0 & -4.8 & -3.1 & -4.3 \\
\hline Gabon & 8.7 & 11.7 & 7.5 & 3.2 & 6.0 & 7.1 \\
\hline CEMAC & 8.4 & 10.3 & -0.9 & 2.2 & 6.2 & 5.5 \\
\hline \multicolumn{7}{|c|}{ Overall fiscal balance (including grants) } \\
\hline Cameroon & 4.5 & 2.3 & -0.1 & -0.9 & -1.0 & -0.2 \\
\hline Central African Republic & 1.2 & -1.0 & 0.0 & -0.7 & -0.1 & 0.2 \\
\hline Chad & 3.1 & 4.5 & -9.9 & -5.5 & 6.3 & 4.8 \\
\hline Congo, Republic of & 9.4 & 23.5 & 4.8 & 15.1 & 30.1 & 30.8 \\
\hline Equatorial Guinea & 19.3 & 15.4 & -8.0 & -4.8 & -3.1 & -4.3 \\
\hline Gabon & 8.7 & 11.7 & 7.5 & 3.2 & 6.0 & 7.1 \\
\hline CEMAC & 8.7 & 10.4 & -0.6 & 2.5 & 7.6 & 7.5 \\
\hline \multicolumn{7}{|l|}{ Basic balance $^{1}$} \\
\hline Cameroon & 4.0 & 2.4 & -0.2 & -0.7 & 0.2 & 1.7 \\
\hline Central African Republic & -2.8 & -4.0 & -4.5 & -5.0 & -4.3 & -5.1 \\
\hline Chad & 8.9 & 5.0 & -10.2 & -5.6 & 7.2 & 3.7 \\
\hline Congo, Republic of & 7.9 & 21.3 & 4.0 & 12.6 & 27.9 & 28.7 \\
\hline Equatorial Guinea & 19.3 & 15.4 & -3.8 & -4.0 & -2.4 & -2.6 \\
\hline Gabon & 9.4 & 12.2 & 8.4 & 7.1 & 7.9 & 8.6 \\
\hline CEMAC & 9.3 & 10.7 & 0.1 & 3.0 & 8.4 & 8.3 \\
\hline \multicolumn{7}{|c|}{ Primary fiscal balance (including grants) } \\
\hline Cameroon & 5.0 & 2.7 & 0.3 & -0.8 & -1.0 & 0.1 \\
\hline Central African Republic & 2.6 & 0.9 & 1.0 & 0.3 & 0.5 & 0.7 \\
\hline Chad & 3.4 & 4.7 & -9.3 & -3.9 & 6.7 & 4.8 \\
\hline Congo, Republic of & 12.7 & 27.0 & 7.1 & 18.7 & 33.0 & 30.8 \\
\hline Equatorial Guinea & 19.4 & 15.4 & -7.9 & -4.7 & -2.7 & -3.9 \\
\hline Gabon & 10.6 & 13.2 & 8.1 & 3.6 & 7.4 & 8.4 \\
\hline CEMAC & 10.3 & 11.4 & 0.0 & 3.0 & 8.2 & 7.7 \\
\hline \multicolumn{7}{|c|}{ Government revenue (excluding grants) } \\
\hline Cameroon & 19.1 & 20.0 & 17.6 & 16.8 & 17.5 & 18.1 \\
\hline Central African Republic & 10.3 & 10.4 & 10.8 & 11.0 & 11.5 & 11.9 \\
\hline Chad & 22.8 & 26.4 & 16.1 & 23.4 & 30.0 & 28.6 \\
\hline Congo, Republic of & 39.1 & 46.6 & 29.2 & 37.8 & 51.7 & 53.2 \\
\hline Equatorial Guinea & 38.3 & 37.0 & 41.0 & 29.9 & 29.0 & 26.9 \\
\hline Gabon & 29.5 & 31.9 & 32.6 & 28.3 & 29.3 & 30.8 \\
\hline CEMAC & 27.8 & 30.6 & 26.0 & 25.5 & 29.3 & 29.4 \\
\hline \multicolumn{7}{|l|}{ Government expenditure } \\
\hline Cameroon & 15.7 & 18.5 & 18.4 & 18.6 & 19.6 & 19.1 \\
\hline Central African Republic & 13.2 & 16.2 & 16.1 & 17.2 & 15.7 & 16.3 \\
\hline Chad & 21.1 & 23.4 & 29.5 & 30.6 & 25.5 & 26.4 \\
\hline Congo, Republic of & 30.0 & 23.8 & 24.7 & 22.7 & 21.9 & 23.2 \\
\hline Equatorial Guinea & 19.0 & 21.6 & 49.0 & 34.6 & 32.2 & 31.2 \\
\hline Gabon & 20.8 & 20.2 & 25.1 & 25.1 & 23.4 & 23.7 \\
\hline CEMAC & 19.5 & 20.3 & 26.9 & 23.3 & 23.1 & 23.8 \\
\hline
\end{tabular}

Sources: IMF, World Economic Outlook database; and staff estimates and projections.

${ }^{1}$ Overall budget balance excluding grants and foreign-financed investment. 
Table 6b. CEMAC: Fiscal Non-oil Balances, 2007-12

(In percent of Non-oil GDP)

\begin{tabular}{|c|c|c|c|c|c|c|}
\hline & 2007 & 2008 & 2009 & $\begin{array}{r}2010 \\
\text { Est. }\end{array}$ & $\begin{array}{c}2011 \\
\text { Proj. }\end{array}$ & $\begin{array}{r}2012 \\
\text { Proj. }\end{array}$ \\
\hline \multicolumn{7}{|l|}{ Non-oil fiscal balance (excluding grants) } \\
\hline Cameroon & -3.5 & -6.8 & -6.1 & -6.5 & -7.1 & -7.4 \\
\hline Central African Republic & -2.9 & -5.8 & -5.3 & -6.1 & -4.1 & -4.4 \\
\hline Chad & -24.2 & -26.5 & -30.0 & -25.4 & -20.1 & -24.3 \\
\hline Congo, Republic of & -66.2 & -58.4 & -43.0 & -37.8 & -43.2 & -37.5 \\
\hline Equatorial Guinea & -55.7 & -75.4 & -109.6 & -78.6 & -76.2 & -70.4 \\
\hline Gabon & -17.6 & -19.6 & -17.1 & -26.0 & -23.5 & -18.6 \\
\hline CEMAC & -17.6 & -22.4 & -25.5 & -23.4 & -23.9 & -22.8 \\
\hline \multicolumn{7}{|l|}{ Non-oil fiscal balance (including grants) } \\
\hline Cameroon & -2.1 & -5.9 & -5.2 & -5.8 & -6.2 & -6.5 \\
\hline Central African Republic & 1.2 & -1.0 & 0.0 & -0.7 & -0.1 & 0.2 \\
\hline Chad & -21.5 & -23.7 & -24.6 & -22.6 & -18.5 & -20.6 \\
\hline Congo, Republic of & -65.1 & -56.1 & -42.1 & -37.2 & -40.4 & -35.2 \\
\hline Equatorial Guinea & -55.7 & -75.4 & -109.6 & -78.6 & -76.2 & -70.4 \\
\hline Gabon & -17.6 & -19.6 & -17.1 & -26.0 & -23.5 & -18.6 \\
\hline CEMAC & -16.6 & -21.4 & -24.4 & -22.7 & -23.0 & -21.8 \\
\hline \multicolumn{7}{|l|}{ Basic balance $^{1}$} \\
\hline Cameroon & 4.4 & 2.7 & -0.2 & -0.8 & 0.2 & 1.8 \\
\hline Central African Republic & -2.8 & -4.0 & -4.5 & -5.0 & -4.3 & -5.1 \\
\hline Chad & 16.2 & 9.2 & -15.3 & -9.0 & 12.2 & 6.2 \\
\hline Congo, Republic of & 22.8 & 72.3 & 10.6 & 38.8 & 95.9 & 90.6 \\
\hline Equatorial Guinea & 73.9 & 60.3 & -9.2 & -10.2 & -6.5 & -6.7 \\
\hline Gabon & 18.7 & 25.2 & 14.9 & 14.0 & 19.7 & 17.1 \\
\hline CEMAC & 16.0 & 19.5 & 0.2 & 5.0 & 14.3 & 13.6 \\
\hline \multicolumn{7}{|c|}{ Non-oil primary fiscal balance (including grants) } \\
\hline Cameroon & -1.6 & -5.5 & -4.9 & -5.4 & -5.7 & -6.0 \\
\hline Central African Republic & 2.6 & 0.9 & 1.0 & 0.3 & 0.6 & 0.8 \\
\hline Chad & -22.1 & -28.7 & -27.3 & -33.5 & -24.6 & -20.2 \\
\hline Congo, Republic of & -55.7 & -44.3 & -36.0 & -34.8 & -34.6 & -35.6 \\
\hline Equatorial Guinea & -49.2 & -67.2 & -103.9 & -73.4 & -71.9 & -67.3 \\
\hline Gabon & -13.3 & -14.8 & -13.9 & -22.9 & -20.1 & -16.6 \\
\hline CEMAC & -14.2 & -19.0 & -22.8 & -22.3 & -21.8 & -20.7 \\
\hline CEMAC (Excluding public investment) & -0.5 & -3.0 & -2.2 & -3.8 & -1.4 & -0.4 \\
\hline \multicolumn{7}{|l|}{ Government revenue (excluding grants) } \\
\hline Cameroon & 21.1 & 22.2 & 18.6 & 18.1 & 18.8 & 19.6 \\
\hline Central African Republic & 10.3 & 10.4 & 10.8 & 11.0 & 11.5 & 11.9 \\
\hline Chad & 41.6 & 49.2 & 25.2 & 38.6 & 46.6 & 40.3 \\
\hline Congo, Republic of & 112.4 & 158.1 & 77.4 & 116.5 & 171.5 & 159.7 \\
\hline Equatorial Guinea & 146.3 & 145.2 & 99.7 & 75.2 & 75.0 & 67.1 \\
\hline Gabon & 58.9 & 65.9 & 57.7 & 55.0 & 60.1 & 59.6 \\
\hline CEMAC & 48.2 & 56.5 & 39.6 & 42.3 & 50.2 & 48.7 \\
\hline \multicolumn{7}{|l|}{ Government expenditure } \\
\hline Cameroon & 17.4 & 20.6 & 19.6 & 20.0 & 21.0 & 20.6 \\
\hline Central African Republic & 13.2 & 16.2 & 16.1 & 17.2 & 15.7 & 16.3 \\
\hline Chad & 38.5 & 43.7 & 46.1 & 50.3 & 39.5 & 37.2 \\
\hline Congo, Republic of & 86.3 & 80.7 & 65.6 & 70.1 & 72.6 & 69.7 \\
\hline Equatorial Guinea & 72.4 & 84.8 & 119.0 & 87.3 & 83.1 & 77.8 \\
\hline Gabon & 41.6 & 41.7 & 44.4 & 48.9 & 47.9 & 45.9 \\
\hline CEMAC & 33.3 & 37.1 & 40.6 & 38.3 & 39.2 & 39.2 \\
\hline
\end{tabular}

Sources: IMF, World Economic Outlook database; and staff estimates and projections.

${ }^{1}$ Overall budget balance excluding grants and foreign-financed investment. 
Table 7. CEMAC: Compliance with Convergence Criteria, 2007-12

(In percent of GDP, unless otherwise indicated)

\begin{tabular}{|c|c|c|c|c|c|c|}
\hline & 2007 & 2008 & 2009 & $\begin{array}{r}2010 \\
\text { Est. }\end{array}$ & $\begin{array}{c}2011 \\
\text { Proj. }\end{array}$ & $\begin{array}{r}2012 \\
\text { Proj. }\end{array}$ \\
\hline & \multicolumn{6}{|c|}{ (Percent of GDP) } \\
\hline \multicolumn{7}{|l|}{ Basic fiscal balance $(\geq 0)^{1}$} \\
\hline Cameroon & 4.0 & 2.4 & -0.2 & -0.7 & 0.2 & 1.7 \\
\hline Central African Republic & -2.8 & -4.0 & -4.5 & -5.0 & -4.3 & -5.1 \\
\hline Chad & 8.9 & 5.0 & -10.2 & -5.6 & 7.2 & 3.7 \\
\hline Congo, Republic of & 7.9 & 21.3 & 4.0 & 12.6 & 27.9 & 28.7 \\
\hline Equatorial Guinea & 19.3 & 15.4 & -3.8 & -4.0 & -2.4 & -2.6 \\
\hline Gabon & 9.4 & 12.2 & 8.4 & 7.1 & 7.9 & 8.6 \\
\hline \multirow[t]{2}{*}{ Number of countries violating } & 1 & 1 & 4 & 4 & 2 & 2 \\
\hline & \multicolumn{6}{|c|}{ (Annual percent change) } \\
\hline \multicolumn{7}{|l|}{ Consumer price inflation $(\leq 3 \%)$} \\
\hline Cameroon & 1.1 & 5.3 & 3.0 & 1.3 & 2.6 & 2.5 \\
\hline Central African Republic & 0.9 & 9.3 & 3.5 & 1.5 & 3.1 & 2.8 \\
\hline Chad & -7.4 & 8.3 & 10.1 & -2.1 & -2.0 & -2.0 \\
\hline Congo, Republic of & 2.6 & 6.0 & 4.3 & 5.0 & 5.9 & 5.2 \\
\hline Equatorial Guinea & 2.8 & 4.3 & 7.2 & 7.5 & 7.3 & 7.0 \\
\hline Gabon & 5.0 & 5.3 & 1.9 & 1.4 & 2.3 & 3.4 \\
\hline \multirow[t]{2}{*}{ Number of countries violating } & 1 & 6 & 5 & 2 & 3 & 3 \\
\hline & \multicolumn{6}{|c|}{ (Percent of GDP) } \\
\hline \multicolumn{7}{|l|}{ Level of public debt ${ }^{2}(\leq 70 \%$ GDP $)$} \\
\hline Cameroon & 11.9 & 9.5 & 9.6 & 12.8 & 14.3 & 14.1 \\
\hline Central African Republic & 79.1 & 80.3 & 33.4 & 33.0 & 27.2 & 23.7 \\
\hline Chad & 26.0 & 23.6 & 30.5 & 32.6 & 29.3 & 28.7 \\
\hline Congo, Republic of & 83.3 & 59.7 & 50.2 & 22.7 & 20.5 & 21.2 \\
\hline Equatorial Guinea & 1.1 & 0.7 & 5.1 & 7.5 & 8.4 & 10.3 \\
\hline Gabon & 43.2 & 20.9 & 26.4 & 25.1 & 21.6 & 19.7 \\
\hline \multirow[t]{2}{*}{ Number of countries violating } & 2 & 1 & 0 & 0 & 0 & 0 \\
\hline & \multicolumn{6}{|c|}{ (Percent of GDP) } \\
\hline \multicolumn{7}{|c|}{ Net change in government arrears $^{3}(\leq 0)$} \\
\hline Cameroon & -0.8 & -0.4 & -0.2 & -1.1 & -3.5 & -0.2 \\
\hline Central African Republic & -1.7 & -0.6 & -0.5 & -1.1 & -1.4 & -1.3 \\
\hline Chad & -0.6 & -2.4 & -2.5 & -2.4 & -2.2 & -2.1 \\
\hline Congo, Republic of & -6.7 & -17.9 & -2.7 & -3.8 & -0.5 & -0.6 \\
\hline Equatorial Guinea & 0.0 & 0.0 & 0.0 & 0.0 & 0.0 & 0.0 \\
\hline Gabon & -0.7 & -2.0 & -4.1 & -2.2 & -0.1 & -0.1 \\
\hline Number of countries violating & 0 & 0 & 0 & 0 & 0 & 0 \\
\hline Total number of criteria violations & 4 & 8 & 9 & 6 & 5 & 5 \\
\hline Cameroon & 0 & 1 & 2 & 1 & 0 & 0 \\
\hline Central African Republic & 2 & 3 & 2 & 1 & 2 & 1 \\
\hline Chad & 0 & 1 & 2 & 1 & 0 & 0 \\
\hline Congo, Republic of & 1 & 1 & 1 & 1 & 1 & 1 \\
\hline Equatorial Guinea & 0 & 1 & 2 & 2 & 2 & 2 \\
\hline Gabon & 1 & 1 & 0 & 0 & 0 & 1 \\
\hline
\end{tabular}

Sources: IMF, World Economic Outlook database; and staff estimates and projections.

${ }^{1}$ Overall budget balance, excluding grants and foreign-financed investment.

${ }^{2}$ External debt only. Calculated by converting the foreign-currency denominated external debt in CFA francs using end-year exchange rates. The CEMAC's convergence criterion also includes domestic debt, on which the World Economic Outlook database provides insufficient information.

${ }^{3}$ External and domestic arrears. 
Table 8. CEMAC: Monetary Survey, 2006-10

\begin{tabular}{|c|c|c|c|c|c|}
\hline & $\begin{array}{l}2006 \\
\text { Dec. }\end{array}$ & $\begin{array}{l}2007 \\
\text { Dec. }\end{array}$ & $\begin{array}{l}2008 \\
\text { Dec. }\end{array}$ & $\begin{array}{l}2009 \\
\text { Dec. }\end{array}$ & $\begin{array}{l}2010 \\
\text { Dec. }\end{array}$ \\
\hline & \multicolumn{5}{|c|}{ (Billions of CFA francs) } \\
\hline Net foreign assets & 4,860 & 6,345 & 7,786 & 7,027 & 6,231 \\
\hline Bank of Central African States (BEAC) & 4,382 & 5,276 & 7,274 & 6,345 & 5,550 \\
\hline Foreign assets & 4,499 & 5,386 & 7,394 & 6,536 & 6,146 \\
\hline \multicolumn{6}{|l|}{ Of which } \\
\hline Operations account & 4,166 & 3,687 & 7,238 & 5,483 & 4,603 \\
\hline Foreign liabilities & -116 & -110 & -121 & -191 & -596 \\
\hline Commercial banks & 478 & 1,069 & 512 & 682 & 682 \\
\hline Foreign assets & 630 & 1,300 & 739 & 957 & 734 \\
\hline Foreign liabilities & -151 & -231 & -227 & -275 & -340 \\
\hline Net domestic assets & -715 & $-1,686$ & $-2,270$ & $-1,170$ & 521 \\
\hline Net credit to government & 768 & 270 & 270 & 667 & 900 \\
\hline BEAC & 559 & 526 & 193 & 529 & 627 \\
\hline Advances & 402 & 367 & 39 & 295 & 526 \\
\hline Consolidated debt & 53 & 77 & 75 & 76 & 78 \\
\hline Other & 105 & 82 & 78 & 158 & 24 \\
\hline Government deposits & $-2,386$ & $-2,789$ & $-3,962$ & $-2,869$ & $-2,687$ \\
\hline Commercial banks & 209 & -256 & 77 & 138 & 273 \\
\hline Net credit to public agencies & -183 & -236 & -251 & -255 & -261 \\
\hline Net credit to private sector & 1,758 & 1,944 & 2,487 & 2,657 & 3,017 \\
\hline Other items, net & $-3,057$ & $-3,664$ & $-4,776$ & $-4,238$ & $-3,135$ \\
\hline Broad money & 4,175 & 4,757 & 5,631 & 6,031 & 6,690 \\
\hline Currency outside banks & 1,122 & 1,200 & 1,458 & 1,525 & 1,556 \\
\hline \multirow[t]{2}{*}{ Bank deposits } & 3,053 & 3,557 & 4,173 & 4,505 & 5,134 \\
\hline & \multicolumn{5}{|c|}{$\begin{array}{l}\text { (Annual change in percent of beginning-of-period broad money } \\
\text { unless otherwise indicated) }\end{array}$} \\
\hline Net foreign assets & 52.8 & 35.6 & 30.3 & -13.5 & -13.2 \\
\hline Net domestic assets & -33.7 & -23.3 & -12.3 & 19.5 & 28.0 \\
\hline Credit to government & -6.8 & -11.9 & 0.0 & 7.0 & 3.9 \\
\hline Credit to the private sector & 4.8 & 4.5 & 11.4 & 3.0 & 6.0 \\
\hline Other & -31.7 & -15.8 & -23.7 & 9.5 & 18.2 \\
\hline Broad money & 19.1 & 13.9 & 18.4 & 7.1 & 10.9 \\
\hline Velocity (GDP/broad money) & 6.6 & 6.2 & 6.3 & 6.9 & 6.5 \\
\hline Broad Money/GDP & 15.2 & 16.1 & 16.0 & 14.5 & 15.4 \\
\hline Private bank Deposits/GDP & 10.1 & 10.8 & 10.7 & 9.5 & 10.9 \\
\hline Credit to the private sector/GDP & 6.4 & 6.6 & 7.0 & 6.4 & 6.9 \\
\hline
\end{tabular}

Sources: BEAC; and staff estimates. 
Table 9. CEMAC: Summary Accounts of Central Bank, 2006-10

\begin{tabular}{|c|c|c|c|c|c|}
\hline & $\begin{array}{l}2006 \\
\text { Dec. }\end{array}$ & $\begin{array}{l}2007 \\
\text { Dec. }\end{array}$ & $\begin{array}{l}2008 \\
\text { Dec. }\end{array}$ & $\begin{array}{c}2009 \\
\text { Dec. }\end{array}$ & $\begin{array}{l}2010 \\
\text { Dec. }\end{array}$ \\
\hline & \multicolumn{5}{|c|}{ (CFAF billions) } \\
\hline Net foreign assets & 4,382 & 5,276 & 7,274 & 6,345 & 5,550 \\
\hline Assets $^{1}$ & 4,499 & 5,386 & 7,394 & 6,536 & 6,146 \\
\hline \multicolumn{6}{|l|}{ Of which } \\
\hline Operations account & 4,166 & 3,687 & 7,238 & 5,483 & 4,603 \\
\hline Liabilities & -116 & -110 & -121 & -191 & -596 \\
\hline Net domestic assets & $-2,014$ & $-2,488$ & $-4,002$ & $-2,888$ & $-1,403$ \\
\hline Net credit to government & 559 & 526 & 193 & 529 & 627 \\
\hline Claims & 559 & 526 & 193 & 529 & 627 \\
\hline Consolidated debt & 53 & 77 & 75 & 76 & 78 \\
\hline Advances & 402 & 367 & 39 & 295 & 526 \\
\hline Cameroon & 166 & 80 & 0 & 0 & 0 \\
\hline Central African Republic & 36 & 16 & 18 & 21 & 22 \\
\hline Chad & 7 & 18 & 22 & 142 & 217 \\
\hline Congo, Republic of & 131 & 154 & 0 & 42 & 42 \\
\hline Equatorial Guinea & 0 & 0 & 0 & 0 & 0 \\
\hline Gabon & 61 & 99 & 0 & 90 & 245 \\
\hline Other claims & 105 & 82 & 78 & 158 & 24 \\
\hline Government deposits & $-2,386$ & $-2,789$ & $-3,962$ & $-2,869$ & $-2,687$ \\
\hline Net claims on financial institutions & 9 & 6 & 6 & 5 & 1 \\
\hline Other items, net & $-2,582$ & $-3,019$ & $-4,201$ & $-3,422$ & $-2,031$ \\
\hline Base money & 2,368 & 2,788 & 3,272 & 3,457 & 4,146 \\
\hline Currency in circulation & 1,122 & 1,200 & 1,458 & 1,525 & 1,556 \\
\hline Banks' reserves ${ }^{2}$ & 1,165 & 1,497 & 1,715 & 1,845 & 2,521 \\
\hline Other institutions' reserves & 57 & 66 & 81 & 68 & 99 \\
\hline \multicolumn{6}{|l|}{ Memorandum items: } \\
\hline Currency cover ratio ${ }^{3}$ & 95.9 & 97.9 & 103.2 & 103.1 & 93.1 \\
\hline Base money/deposits & 80.5 & 82.8 & 82.7 & 81.5 & 80.9 \\
\hline
\end{tabular}

Sources: Bank of Central African States (BEAC); and staff estimates.

${ }^{1}$ Gross foreign reserves, including gold, foreign currency reserves, IMF reserve position, and balance of the operations account at the French Treasury.

${ }^{2}$ Includes cash in vault and deposits of commercial banks with the BEAC.

${ }^{3}$ Gross operations account official reserves as a percentage of base money. 
Table 10. CEMAC: Summary Accounts of Commercial Banks, 2006-10

\begin{tabular}{|c|c|c|c|c|c|}
\hline & $\begin{array}{c}2006 \\
\text { Dec. }\end{array}$ & $\begin{array}{c}2007 \\
\text { Dec. }\end{array}$ & $\begin{array}{c}2008 \\
\text { Dec. }\end{array}$ & $\begin{array}{c}2009 \\
\text { Dec. }\end{array}$ & $\begin{array}{l}2010 \\
\text { Dec }\end{array}$ \\
\hline & \multicolumn{5}{|c|}{ (CFAF billions) } \\
\hline Net foreign assets & 478 & 1,069 & 512 & 682 & 682 \\
\hline Assets & 630 & 1,300 & 739 & 957 & 957 \\
\hline Liabilities & -151 & -231 & -227 & -275 & -275 \\
\hline Net domestic assets & 1,308 & 807 & 1,738 & 1,723 & 1,925 \\
\hline Net credit to public sector & 25 & -492 & -174 & -118 & 12 \\
\hline Cameroon & 30 & 3 & -27 & -70 & 99 \\
\hline Central African Republic & 14 & 18 & 21 & 17 & 16 \\
\hline Chad & 56 & 58 & 70 & 73 & 79 \\
\hline Congo, Republic of & -10 & -13 & -7 & -1 & -1 \\
\hline Equatorial Guinea & -111 & -122 & -264 & -150 & -190 \\
\hline Gabon & 47 & -435 & 33 & 12 & 9 \\
\hline Claims & 559 & 526 & 193 & 529 & 529 \\
\hline Liabilities & 451 & 1,037 & 696 & 665 & 665 \\
\hline Credit to the economy & 1,758 & 1,944 & 2,487 & 2,657 & 3,017 \\
\hline Cameroon & 859 & 910 & 1,088 & 1,188 & 1,285 \\
\hline Central African Republic & 51 & 55 & 62 & 66 & 87 \\
\hline Chad & 137 & 120 & 178 & 202 & 224 \\
\hline Congo, Republic of & 84 & 91 & 167 & 218 & 325 \\
\hline Equatorial Guinea & 125 & 175 & 362 & 404 & 505 \\
\hline Gabon & 503 & 593 & 629 & 579 & 590 \\
\hline Other items, net & -476 & -645 & -575 & -816 & $-1,104$ \\
\hline Net refinancing from central bank & $-1,157$ & $-1,491$ & $-1,709$ & $-1,840$ & $-2,516$ \\
\hline Borrowing & 9 & 6 & 6 & 5 & 5 \\
\hline Cameroon & 0 & 0 & 0 & 0 & 0 \\
\hline Central African Republic & 0 & 0 & 0 & 0 & 0 \\
\hline Chad & 9 & 3 & 6 & 5 & 5 \\
\hline Congo, Republic of & 0 & 3 & 0 & 0 & 0 \\
\hline Equatorial Guinea & 0 & 0 & 0 & 0 & 0 \\
\hline Gabon & 0 & 0 & 0 & 0 & 0 \\
\hline Reserves & 1,165 & 1,497 & 1,715 & 1,845 & 2,521 \\
\hline Cameroon & 521 & 678 & 644 & 732 & 942 \\
\hline Central African Republic & 3 & 9 & 9 & 27 & 17 \\
\hline Chad & 74 & 76 & 72 & 76 & 156 \\
\hline Congo, Republic of & 138 & 205 & 342 & 264 & 391 \\
\hline Equatorial Guinea & 213 & 280 & 233 & 373 & 568 \\
\hline Gabon & 216 & 249 & 415 & 372 & 446 \\
\hline Deposits & 2,943 & 3,368 & 3,959 & 4,244 & 5,123 \\
\hline Demand deposits & 1,665 & 2,038 & 2,516 & 2,688 & 3,383 \\
\hline Public enterprises & 132 & 165 & 146 & 214 & 285 \\
\hline Private sector & 1,534 & 1,873 & 2,370 & 2,474 & 3,098 \\
\hline Term deposits & 1,277 & 1,330 & 1,442 & 1,556 & 1,740 \\
\hline Public enterprises & 30 & 26 & 53 & 57 & 113 \\
\hline Private sector & 1,247 & 1,304 & 1,390 & 1,498 & 1,627 \\
\hline \multicolumn{6}{|l|}{ Memorandum items: } \\
\hline Reserves/deposits & 39.6 & 44.5 & 43.3 & 43.5 & 49.2 \\
\hline Credit to the economy/deposits & 59.7 & 57.7 & 62.8 & 62.6 & 58.9 \\
\hline
\end{tabular}

Sources: Bank of Central African States (BEAC); and staff estimates. 
Table 11. CEMAC: Summary Medium-Term Projections, 2007-16

\begin{tabular}{|c|c|c|c|c|c|c|c|c|c|c|}
\hline & 2007 & 2008 & 2009 & 2010 & 2011 & 2012 & 2013 & 2014 & 2015 & 2016 \\
\hline & & & & & Proj. & Proj. & Proj. & Proj. & Proj. & Proj. \\
\hline National income and prices & \multicolumn{10}{|c|}{ (Annual Percent Change) } \\
\hline Real GDP & 5.9 & 4.3 & 2.4 & 5.0 & 5.2 & 4.2 & 4.6 & 3.9 & 3.0 & 2.7 \\
\hline Oil & 3.7 & 3.5 & -4.9 & -2.4 & 1.7 & 3.8 & -0.1 & 0.4 & -5.0 & -10.0 \\
\hline Non-oil & 11.8 & 5.9 & 6.2 & 5.2 & 6.8 & 5.4 & 7.5 & 5.7 & 4.9 & 5.7 \\
\hline GDP deflator & 1.4 & 13.4 & -15.6 & 13.1 & 9.1 & 0.2 & 0.0 & 0.6 & 1.0 & 0.3 \\
\hline Nominal GDP & 7.4 & 19.5 & -14.4 & 18.9 & 15.9 & 4.4 & 4.5 & 4.0 & 3.9 & 2.3 \\
\hline Consumer prices (average) & 1.0 & 5.7 & 4.7 & 2.7 & 4.1 & 3.9 & 3.7 & 3.5 & 3.5 & 3.4 \\
\hline \multicolumn{11}{|l|}{ External sector } \\
\hline Exports, f.o.b & 30.2 & 31.2 & -32.8 & 27.0 & 31.5 & 0.8 & -1.3 & -0.9 & -2.1 & -5.2 \\
\hline Export volume & 3.0 & -3.1 & 2.1 & -8.1 & 2.9 & 6.2 & 6.0 & 5.0 & 2.3 & 0.7 \\
\hline Imports, c.i.f. & 15.3 & 28.0 & -2.0 & 11.6 & 21.0 & -1.2 & 1.8 & 2.5 & 1.9 & 2.5 \\
\hline Import volume & 12.1 & 9.2 & 15.9 & 6.7 & 9.3 & -2.4 & 1.2 & 2.3 & 1.7 & 0.5 \\
\hline Terms of trade & 9.1 & -6.2 & -18.0 & 16.7 & 11.8 & -4.6 & 0.6 & 0.5 & -2.0 & -1.5 \\
\hline Central government & \multicolumn{10}{|c|}{ (Percent of GDP) } \\
\hline Overall balance, including grants & 8.7 & 10.4 & -0.6 & 2.5 & 7.6 & 7.5 & 7.0 & 6.6 & 6.0 & 5.3 \\
\hline Grants & 0.7 & 0.6 & 0.9 & 0.6 & 0.6 & 0.7 & 0.7 & 0.7 & 0.8 & 0.8 \\
\hline Total revenue and grants & 28.6 & 31.2 & 26.9 & 26.0 & 29.9 & 30.1 & 29.5 & 29.0 & 28.3 & 27.7 \\
\hline Total expenditure and net lending & 19.5 & 20.3 & 26.9 & 23.3 & 23.1 & 23.8 & 23.4 & 23.6 & 23.5 & 24.1 \\
\hline \multicolumn{11}{|l|}{ External sector } \\
\hline Current account balance, including grants & 4.7 & 7.2 & -5.5 & -2.8 & 0.7 & 2.0 & 1.4 & 0.9 & 0.1 & -1.2 \\
\hline \multirow[t]{2}{*}{ Trade balance } & 20.5 & 22.0 & 4.8 & 11.1 & 15.2 & 15.5 & 13.6 & 11.8 & 9.8 & 6.4 \\
\hline & \multicolumn{10}{|c|}{ (Percent of Non-oil GDP) } \\
\hline Overall balance, excluding grants & 14.5 & 17.8 & -2.6 & 2.8 & 11.4 & 10.7 & 9.0 & 8.1 & 7.1 & 6.0 \\
\hline Non-oil overall balance & -16.6 & -21.4 & -24.4 & -22.7 & -23.0 & -21.8 & -18.8 & -17.1 & -15.4 & -13.8 \\
\hline Non-oil primary balance & -14.2 & -19.0 & -22.8 & -22.3 & -21.8 & -20.7 & -18.2 & -17.1 & -15.8 & -14.6 \\
\hline
\end{tabular}

Sources: IMF, World Economic Outlook database; and staff estimates and projections. 
Table 12. CEMAC: Relative Size of CEMAC Economies and Importance of Oil Sector, 2007-16

\begin{tabular}{|c|c|c|c|c|c|c|c|c|c|c|}
\hline & 2007 & 2008 & 2009 & 2010 & $\begin{array}{l}2011 \\
\text { Proj. }\end{array}$ & $\begin{array}{l}2012 \\
\text { Proj. }\end{array}$ & $\begin{array}{l}2013 \\
\text { Proj. }\end{array}$ & $\begin{array}{l}2014 \\
\text { Proj. }\end{array}$ & $\begin{array}{l}2015 \\
\text { Proj. }\end{array}$ & $\begin{array}{c}2016 \\
\text { Proj. }\end{array}$ \\
\hline Nominal GDP & \multicolumn{10}{|c|}{ (In percent of CEMAC'S nominal GDP) } \\
\hline Cameroon & 33.2 & 30.1 & 34.7 & 30.9 & 28.8 & 29.6 & 30.3 & 31.3 & 31.9 & 33.3 \\
\hline Central African Republic & 2.8 & 2.5 & 3.1 & 2.8 & 2.6 & 2.7 & 2.8 & 2.9 & 3.0 & 3.2 \\
\hline Chad & 11.4 & 10.6 & 10.9 & 10.8 & 11.0 & 11.6 & 11.3 & 11.2 & 11.1 & 11.3 \\
\hline Congo, Republic of & 13.5 & 15.0 & 15.0 & 15.9 & 18.7 & 18.6 & 17.6 & 17.0 & 17.1 & 17.2 \\
\hline Equatorial Guinea & 20.4 & 23.4 & 19.1 & 20.0 & 22.3 & 23.0 & 23.6 & 23.9 & 23.3 & 21.9 \\
\hline Gabon & 18.8 & 18.4 & 17.1 & 18.0 & 23.7 & 19.5 & 18.6 & 18.3 & 18.1 & 18.5 \\
\hline CEMAC & 100.0 & 100.0 & 100.0 & 100.0 & 100.0 & 100.0 & 100.0 & 100.0 & 100.0 & 100.0 \\
\hline Nominal oil GDP (percent of CEMAC) & \multicolumn{10}{|c|}{ (In percent of CEMAC'S nominal GDP) } \\
\hline Cameroon & 3.2 & 3.0 & 2.0 & 2.1 & 2.1 & 2.6 & 2.9 & 3.3 & 3.0 & 3.1 \\
\hline Central African Republic & 0.0 & 0.0 & 0.0 & 0.0 & 0.0 & 0.0 & 0.0 & 0.0 & 0.0 & 0.0 \\
\hline Chad & 5.1 & 4.8 & 3.6 & 4.1 & 4.5 & 4.7 & 4.3 & 4.0 & 3.7 & 3.6 \\
\hline Congo, Republic of & 8.8 & 10.5 & 9.3 & 10.6 & 13.5 & 12.8 & 11.3 & 9.8 & 9.1 & 7.8 \\
\hline Equatorial Guinea & 15.1 & 17.4 & 11.3 & 12.0 & 13.9 & 14.2 & 13.2 & 12.8 & 11.9 & 9.9 \\
\hline Gabon & 9.4 & 9.5 & 7.4 & 8.8 & 14.1 & 9.7 & 8.4 & 7.9 & 7.6 & 7.5 \\
\hline CEMAC & 41.6 & 45.3 & 33.6 & 37.5 & 48.1 & 44.0 & 40.1 & 37.9 & 35.5 & 31.9 \\
\hline Nominal oil GDP & \multicolumn{10}{|c|}{ (In percent of country's nominal GDP) } \\
\hline Cameroon & 9.6 & 10.1 & 5.8 & 6.7 & 7.3 & 8.7 & 9.6 & 10.6 & 9.5 & 9.3 \\
\hline Central African Republic & 0.0 & 0.0 & 0.0 & 0.0 & 0.0 & 0.0 & 0.0 & 0.0 & 0.0 & 0.0 \\
\hline Chad & 45.2 & 45.7 & 33.0 & 37.8 & 40.9 & 40.8 & 37.8 & 35.6 & 33.6 & 31.9 \\
\hline Congo, Republic of & 65.2 & 70.5 & 62.3 & 66.5 & 72.0 & 69.2 & 64.1 & 57.6 & 53.2 & 45.7 \\
\hline Equatorial Guinea & 73.8 & 74.5 & 58.9 & 60.3 & 62.5 & 61.5 & 55.9 & 53.6 & 51.1 & 45.1 \\
\hline Gabon & 49.9 & 51.5 & 43.4 & 48.9 & 59.7 & 49.7 & 44.9 & 43.3 & 42.1 & 40.5 \\
\hline CEMAC & 41.6 & 45.3 & 33.6 & 37.5 & 48.1 & 44.0 & 40.1 & 37.9 & 35.5 & 31.9 \\
\hline Oil exports & \multicolumn{10}{|c|}{ (In percent of country's total goods exports) } \\
\hline Cameroon & 50.9 & 53.5 & 40.4 & 40.2 & 39.0 & 45.7 & 49.9 & 52.9 & 50.3 & 50.1 \\
\hline Central African Republic & 0.0 & 0.0 & 0.0 & 0.0 & 0.0 & 0.0 & 0.0 & 0.0 & 0.0 & 0.0 \\
\hline Chad & 84.7 & 86.9 & 75.5 & 82.4 & 83.4 & 84.5 & 83.6 & 82.7 & 81.8 & 81.0 \\
\hline Congo, Republic of & 91.1 & 90.3 & 89.3 & 88.2 & 88.7 & 87.8 & 85.8 & 82.9 & 80.7 & 76.7 \\
\hline Equatorial Guinea & 99.0 & 99.3 & 98.7 & 98.2 & 98.5 & 98.6 & 98.6 & 98.5 & 98.4 & 98.1 \\
\hline Gabon & 83.0 & 80.0 & 87.3 & 86.5 & 87.8 & 82.9 & 82.0 & 81.2 & 80.4 & 78.5 \\
\hline CEMAC & 84.7 & 85.1 & 84.3 & 84.5 & 84.9 & 84.2 & 83.4 & 82.1 & 80.1 & 76.6 \\
\hline Fiscal oil revenue & \multicolumn{10}{|c|}{ (In percent of country's fiscal revenue) } \\
\hline Cameroon & 31.8 & 36.6 & 26.3 & 25.6 & 25.9 & 27.4 & 28.0 & 30.3 & 27.0 & 26.3 \\
\hline Central African Republic & 0.0 & 0.0 & 0.0 & 0.0 & 0.0 & 0.0 & 0.0 & 0.0 & 0.0 & 0.0 \\
\hline Chad & 73.6 & 78.7 & 52.6 & 65.5 & 72.0 & 65.3 & 62.0 & 59.9 & 55.9 & 52.1 \\
\hline Congo, Republic of & 81.3 & 84.8 & 70.0 & 78.8 & 83.3 & 78.0 & 72.7 & 65.2 & 59.4 & 48.5 \\
\hline Equatorial Guinea & 88.5 & 93.5 & 90.6 & 88.4 & 90.4 & 90.2 & 88.5 & 87.7 & 86.8 & 85.9 \\
\hline Gabon & 58.6 & 65.5 & 49.7 & 53.9 & 60.0 & 55.6 & 52.7 & 50.8 & 49.3 & 47.2 \\
\hline CEMAC & 64.9 & 71.9 & 58.0 & 65.3 & 70.2 & 68.7 & 64.5 & 62.0 & 58.9 & 56.0 \\
\hline
\end{tabular}

Sources: IMF, World Economic Outlook database; and staff estimates and projections. 
Table 13. CEMAC: Violations of Main Prudential Ratios, 2008-10

\begin{tabular}{|c|c|c|c|c|c|c|c|c|c|c|c|c|c|c|c|c|c|c|}
\hline & \multicolumn{3}{|c|}{ Capital Adequacy } & \multicolumn{3}{|c|}{ Liquidity $^{1}$} & \multicolumn{3}{|c|}{ Fixed assets ${ }^{2}$} & \multicolumn{3}{|c|}{$\begin{array}{c}\text { Maturity }^{3} \\
\text { transformation }\end{array}$} & \multicolumn{3}{|c|}{$\begin{array}{c}\text { Minimum } \\
\text { capital }\end{array}$} & \multicolumn{3}{|c|}{$\begin{array}{l}\text { Limit on single } \\
\text { large exposure }\end{array}$} \\
\hline & 2008 & 2009 & 2010 & 2008 & 2009 & 2010 & 2008 & 2009 & 2010 & 2008 & 2009 & 2010 & 2008 & 2009 & 2010 & 2008 & 2009 & 2010 \\
\hline & \multicolumn{3}{|c|}{$8 \%$} & \multicolumn{3}{|c|}{$\min 100 \%$} & & & & \multicolumn{3}{|c|}{$\min 50 \%$} & & & & \multicolumn{3}{|c|}{ 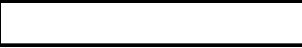 } \\
\hline \multicolumn{19}{|l|}{ Country (number of banks) } \\
\hline Cameroon (13) in 2008 & 2 & 3 & 3 & 0 & 0 & 0 & 2 & 4 & 5 & 1 & 4 & 6 & 1 & 1 & 4 & 6 & 2 & 4 \\
\hline Central African Republic (4) in 2008 & 1 & 2 & 1 & 1 & 0 & 1 & 1 & 3 & 2 & 1 & 2 & 1 & 0 & 0 & 2 & 2 & 2 & 1 \\
\hline Chad (7) in 2008 & 3 & 3 & 2 & 1 & 1 & 1 & 1 & 1 & 3 & 2 & 1 & 2 & 1 & 1 & 4 & 6 & 1 & 4 \\
\hline Congo, Republic (6) in 2008 & 0 & 0 & 0 & 0 & 0 & 0 & 1 & 0 & 0 & 0 & 0 & 0 & 0 & 0 & 2 & 2 & 0 & 2 \\
\hline Equatorial Guinea (4) in 2008 & 1 & 2 & 1 & 0 & 0 & 0 & 2 & 1 & 0 & 1 & 1 & 1 & 1 & 0 & 0 & 0 & 0 & 0 \\
\hline Gabon (7) in 2008 & 0 & 1 & 0 & 0 & 2 & 1 & 1 & 3 & 0 & 0 & 2 & 0 & 0 & 0 & 1 & 1 & 1 & 1 \\
\hline \multirow{2}{*}{ CEMAC (41) in 2008} & 7 & 11 & 7 & 2 & 3 & 3 & 8 & 12 & 10 & 5 & 10 & 10 & 3 & 2 & 13 & 17 & 6 & 12 \\
\hline & \multicolumn{18}{|c|}{ In percent of deposits ${ }^{6}$} \\
\hline Cameroon (13) in 2008 & 11 & 27 & 17 & 0 & 0 & 0 & 3 & 14 & 39 & 1 & 30 & 45 & 1 & 6 & 13 & 35 & 9 & 19 \\
\hline Central African Republic (4) in 2008 & 33 & 81 & 21 & 33 & 0 & 18 & 33 & 85 & 75 & 33 & 81 & 21 & 0 & 0 & 29 & 19 & 81 & 21 \\
\hline Chad (7) in 2008 & 36 & 40 & 27 & 5 & 10 & 6 & 1 & 10 & 31 & 1 & 10 & 27 & 1 & 10 & 40 & 14 & 10 & 61 \\
\hline Congo, Republic (6) in 2008 & 0 & 0 & 0 & 0 & 0 & 0 & 4 & 0 & 0 & 0 & 0 & 0 & 0 & 0 & 10 & 50 & 0 & 41 \\
\hline Equatorial Guinea (4) in 2008 & 5 & 42 & 11 & 0 & 0 & 0 & 10 & 6 & 0 & 5 & 6 & 11 & 5 & 0 & 0 & 0 & 0 & 0 \\
\hline Gabon (7) in 2008 & 0 & 0 & 0 & 0 & 1 & 0 & 32 & 5 & 0 & 0 & 35 & 0 & 0 & 0 & 0 & 93 & 0 & 0 \\
\hline
\end{tabular}

Sources: Banking Commission of Central Africa (COBAC) and staff calculations.

${ }^{1}$ Short term assets of up to one month (remaining maturity) over short term liabilities of up to one month (remaining maturity).

${ }^{2}$ Net capital and other premanent resources over fixed assets.

${ }^{3}$ Long term assets of more than five years over long term liabilities of more than five years.

${ }^{4}$ Minimum capital varies by country (in million CFA): Cameroon 1000; Central African Republic 200; Chad 150; Republic of Congo 150; Equatorial Guinea 300; Gabon 1000.

${ }^{5}$ Single large exposure is limited to 45 percent of capital.

${ }^{6}$ Percentage of deposits represented by the number of banks in violation in the country. 
Table 14. CEMAC: Bank Ratings, December $2010^{1}$ (Number of banks)

\begin{tabular}{lcccccccc}
\hline & 1 & 2 & $3 \mathrm{~A}$ & $3 \mathrm{~B}$ & $3 \mathrm{C}$ & $4 \mathrm{~A}$ & $4 \mathrm{~B}$ & Not Rated \\
\hline Cameroon (13) & 1 & 7 & 0 & 0 & 0 & 1 & 1 & 3 \\
Central African Republic (5) & 0 & 2 & 0 & 0 & 1 & 0 & 0 & 2 \\
Chad (8) & 0 & 3 & 0 & 2 & 0 & 1 & 0 & 2 \\
Congo, Republic of (7) & 1 & 3 & 0 & 0 & 0 & 0 & 0 & 3 \\
Equatorial Guinea (4) & 1 & 2 & 0 & 1 & 0 & 0 & & 0 \\
Gabon (9) & 1 & 5 & 0 & 0 & 0 & 0 & 0 & 3 \\
CEMAC (46) & 4 & 22 & 0 & 3 & 1 & 2 & 1 & 13 \\
\hline
\end{tabular}

Source: Banking Commission of Central Africa (COBAC).

${ }^{1}$ Ratings: $1=$ strong; $2=$ good; $3 A=$ fragile; $3 B=$ moderately fragile; $3 C=$ highly fragile; $4 A=$ critical; and $4 \mathrm{~B}=$ highly critical. 
Table 15. CEMAC : Quality of loan portfolio, 2009-10

(In billions of CFA francs ; Unless otherwise indicated)

\begin{tabular}{|c|c|c|c|c|c|c|c|c|c|c|}
\hline & \multicolumn{2}{|c|}{ Gross loans } & \multicolumn{2}{|c|}{ Non-performing loans } & \multicolumn{2}{|c|}{$\begin{array}{l}\text { Provisions against non- } \\
\text { performing loans }\end{array}$} & \multicolumn{2}{|c|}{$\begin{array}{c}\text { Share of non-performing } \\
\text { loans (In percent of gross } \\
\text { loans) }\end{array}$} & \multicolumn{2}{|c|}{$\begin{array}{l}\text { Rate of Provisioning (In } \\
\text { percent of non-performing } \\
\text { loans) }\end{array}$} \\
\hline & 2009 & 2010 & 2009 & 2010 & 2009 & 2010 & 2009 & 2010 & 2009 & 2010 \\
\hline Cameroon & 1428.6 & $\overline{1600.6}$ & 140.1 & 199.2 & 145.1 & 177.7 & 9.8 & 12.4 & 103.6 & 89.2 \\
\hline Central African Republic & 92.0 & 116.1 & 15.4 & 15.4 & 14.4 & 14.9 & 16.7 & 13.3 & 93.5 & 96.8 \\
\hline Republic of Congo & 258.9 & 379.3 & 2.9 & 4.2 & 3.8 & 4.7 & 1.1 & 1.1 & 131.0 & 111.9 \\
\hline Gabon & 681.4 & 818.4 & 38.4 & 34.6 & 34.8 & 31.4 & 5.6 & 4.2 & 90.6 & 90.8 \\
\hline Equatorial Guinea & 467.3 & 627.7 & 40.2 & 33.5 & 35.4 & 39.8 & 8.6 & 5.3 & 88.1 & 118.8 \\
\hline Gabon & 256.3 & 294.9 & 21.4 & 31.4 & 17.2 & 26.3 & 8.3 & 10.6 & 80.4 & 83.8 \\
\hline CEMAC & 3184.6 & 3837.0 & 258.5 & 318.2 & 250.9 & 294.9 & 8.1 & 8.3 & 97.1 & 92.7 \\
\hline
\end{tabular}

Sources : Banking Commission of Central Africa (COBAC) and staff calculations. 


\section{APPENDIX 1. CEMAC: External Stability Assessment}

Staff's assessment of CEMAC's external sustainability and the real effective exchange rate (REER) suggests that, under current policies, the external position and the REER are broadly consistent with equilibrium. However, poor export performance and weak structural policies underline the need to improve competitiveness.

\section{Developments in the REER}

The REER has appreciated, eroding the competiveness gained after the devaluation of 1994. However, despite the dominant oil sector in the CEMAC, the REER appreciation closely tracked that of the WAEMU, where the oil sector is marginal.

\section{Model-based assessment of the REER}

Using the Bems and Carvalho (2009) ${ }^{1}$ model, which calls for smoothing intertemporal consumption from oil wealth, we derive a current account norm under two different allocation rules. The exchange rate assessment compares this norm to the underlying 2015 current account, which is heavily influenced by the temporarily high public investment. This

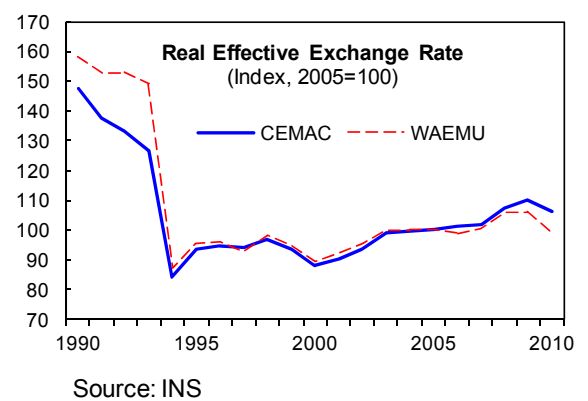
amounts to a very stringent test because the norm presumes that investment should be smoothed across generations. Comparing this norm to the underlying (medium-term) current account deficit yields an overvaluation of about 4 to 11 percent. Allowing for

\begin{tabular}{lccc}
\multicolumn{3}{c}{ CEMAC exchange rate assessments, 2015 } \\
\hline & \multicolumn{2}{c}{ Bems/Carvalho } & $\begin{array}{l}\text { External } \\
\text { sustainability }\end{array}$ \\
\cline { 2 - 3 } & $\begin{array}{l}\text { Constant real } \\
\text { consumption }\end{array}$ & $\begin{array}{c}\text { Constant real per } \\
\text { capita consumption }\end{array}$ & \\
MT Current account Norm & 1.80 & 4.10 & 1.22 \\
Underlying Current account & 0.07 & 0.07 & 0.07 \\
Current account elasticity & 0.37 & 0.37 & 0.37 \\
Overvaluation & 4.69 & 10.90 & 3.13 \\
\hline Source: IMF staff estimates. & & &
\end{tabular}
temporarily higher public investment, the current account could be judged to be broadly consistent with equilibrium.

The external sustainability approach — based on stabilizing the NFA at the 2010 levelpoints to an overvaluation below 4 percent, which is well within the margin of errors. Given the high degree of uncertainty surrounding the above exercise and the data limitations, we complement the analysis with a discussion of reserve adequacy.

\footnotetext{
${ }^{1}$ Bems, Rudolfs, and Irineu de Carvalho Filho, 2009, "Exchange Rate Assessments: Methodologies for Oil Exporting Countries,” IMF Working Paper, No. 09/281.
} 


\section{Reserves adequacy}

With gross international reserves at about 4.5 months of total imports (including investment and oil imports) and 100 percent of broad money, the fixed exchange rate regime is adequately secured. Analyses of reserves adequacy in the CEMAC show that coverage of about 4.5 months of total imports would allow the region to withstand a two-standarddeviation shock to the trade balance.

Under current fiscal policies, gross international reserves are projected to stabilize at about 4 months of total imports by 2015 . The projections are highly sensitive to oil price projections. A risk to this outlook over the longer term is possible widespread noncompliance with full repatriation of export receipts. Low interest rates on CFAF-denominated government deposits at the BEAC discourage full repatriation of export receipts. In addition, recent safeguards concerns at the BEAC have weakened the member states' confidence in the $\mathrm{BEAC}$, thus reducing the incentive for repatriating foreign currency receipts.

Overall, the union's REER, current account, and reserves are broadly consistent with external stability. ${ }^{2}$ A downside risk to the fixed exchange rate regime over the longer term stems from noncompliance with the rule for full repatriation of export receipts to the BEAC.

\section{Non-oil export performance and competitiveness}

CEMAC's export performance suggests there is room for improving competitiveness in the non-commodity sectors. CEMAC's non-oil exports have been stagnated at about 0.05 percent of world exports. At the same time, CEMAC's non-commodity exports growth between 2000 and 2008 has been lagging behind SSA (4.5 percent compared with 14.2 percent).

Structural factors have been a constraint to competitiveness. According to the World Bank's 2011 Doing Business Indicators, CEMAC's average ranking is lower that SSA average (172 compared with 137 out of
CEMAC: Exports of Goods, 1995-2010

(In percent of total world exports)

\begin{tabular}{llll}
\hline & 1995 & 2005 & 2010 \\
\hline Total Exports of Goods & 0.12 & 0.23 & 0.24 \\
Oil & 1.27 & 1.72 & 1.60 \\
Non-oil & 0.05 & 0.04 & 0.04 \\
\hline
\end{tabular}

Source: IMF World Economic Outlook and Staff estimates.

\begin{tabular}{lcc}
\multicolumn{3}{c}{ Trading across borders indicators (2009) } \\
\hline $\begin{array}{c}\text { Time to } \\
\text { export (days) }\end{array}$ & $\begin{array}{c}\text { Cost per } \\
\text { exports }\end{array}$ \\
\hline CEMAC & 40 & 2682 \\
WAEMU & 31 & 1836 \\
SACU & 31 & 2057 \\
\hline
\end{tabular}

Source: World Bank's Doing Business Report.

$1 /$ In US\$ per container.

\footnotetext{
${ }^{2}$ Compared to the oil price projections underlying the previous exchange rate assessment, oil prices are projected to increase markedly, thus improving CEMAC's external position.
} 
183 countries). CEMAC countries ranked very low, with Chad and the C.A.R., having the lowest ranking in the world, closely followed by Congo. ${ }^{3}$ Areas where they fared worst include starting business, paying taxes, enforcing contracts, and trading across borders.

\footnotetext{
${ }^{3}$ A similar conclusion can be drawn from other competitiveness indicators, such as World Economic Forum's competitiveness index and World Bank's CPIA rating for business regulatory environment.
} 


\section{APPENDIX 2. FSAP Recommendations-Status of Implementation}

\begin{tabular}{|c|c|}
\hline Recommendations & Status of Implementation \\
\hline \multicolumn{2}{|c|}{ FINANCIAL SECTOR SUPERVISION AND BANKING SECTOR STABILITY } \\
\hline Increase staffing of COBAC (the banking sector regulator). & $\begin{array}{l}\text { Staffing levels increased, but acute supervisory shortages } \\
\text { continue to impede monitoring and enforcement. }\end{array}$ \\
\hline $\begin{array}{l}\text { Bring prudential framework into line with international standards } \\
\text { and strengthen enforcement. }\end{array}$ & $\begin{array}{l}\text { In progress. The principal prudential regulations (solvency, large } \\
\text { exposures, and connected lending) are out of line with } \\
\text { international best practices and poorly enforced, thus } \\
\text { encouraging excessive credit concentration and exposing the } \\
\text { banking system to credit risk. Enforcement capacity is } \\
\text { constrained by staffing shortages. }\end{array}$ \\
\hline $\begin{array}{l}\text { Increase minimum capital adequacy ratios to reflect specific } \\
\text { CEMAC risks and vulnerabilities. }\end{array}$ & $\begin{array}{l}\text { Minimum capital requirements for credit institutions increased } \\
\text { and harmonized. The banking sector was given a transitory } \\
\text { period of five years to comply with new regulation. }\end{array}$ \\
\hline $\begin{array}{l}\text { Limit powers of national authorities regarding issuance and } \\
\text { withdrawal of bank licenses. }\end{array}$ & $\begin{array}{l}\text { Expected to be addressed by a new regulation on banking crisis } \\
\text { resolution in } 2012 \text {. }\end{array}$ \\
\hline $\begin{array}{l}\text { Streamline reporting and regulatory requirements for microfinance } \\
\text { institutions. }\end{array}$ & $\begin{array}{l}\text { Special microfinance chart of accounts introduced in } 2010 \text { along } \\
\text { with automated IT system to collect financial data. }\end{array}$ \\
\hline \multicolumn{2}{|c|}{ SYSTEMIC LIQUIDITY MANAGEMENT AND RECYCLING OF FISCAL SURPLUSES } \\
\hline Centralize government cash holdings at the BEAC. & Government cash holdings largely centralized at the BEAC. \\
\hline $\begin{array}{l}\text { Reinforce use of market based instruments for monetary and public } \\
\text { debt management. }\end{array}$ & $\begin{array}{l}\text { Statutory advances being phased out beginning 2011; } \\
\text { establishment of institutional framework for regional government } \\
\text { securities market (not yet operational) and BEAC Research } \\
\text { Directorate paved the way for the modernization of monetary } \\
\text { policy. }\end{array}$ \\
\hline $\begin{array}{l}\text { Establish framework to assess desirable target for international } \\
\text { reserves. }\end{array}$ & In progress. Monetary programming needs to be strengthened. \\
\hline \multicolumn{2}{|c|}{ ACCESS TO FINANCIAL SERVICES } \\
\hline $\begin{array}{l}\text { Bring controlled interest rates into line with market fundamentals to } \\
\text { foster financial intermediation. }\end{array}$ & $\begin{array}{l}\text { Interest rates liberalized (cap on lending rates eliminated) and } \\
\text { negative spread vis-à-vis euro rates closed in } 2008 .\end{array}$ \\
\hline $\begin{array}{l}\text { Develop credit bureaus and centralized information registries to } \\
\text { improve creditor information. }\end{array}$ & In process, with World Bank technical assistance. \\
\hline $\begin{array}{l}\text { Enhance the legal and judicial framework and strengthen financial } \\
\text { infrastructure. }\end{array}$ & $\begin{array}{l}\text { Regular publication of lending costs to promote transparency and } \\
\text { competition; establishment of credit bureaus and corporate } \\
\text { balance-sheet registry. }\end{array}$ \\
\hline
\end{tabular}




\section{APPENDIX 3. Infrastructure and Growth ${ }^{1}$}

Rapidly rising oil incomes since the early 2000s have made the CEMAC countries more prosperous. All CEMAC members except Central African Republic are endowed with oil and have benefitted from increased oil exports and consequently fiscal revenue. The abundance of oil revenue, however, has not translated to higher standards of living for the people in CEMAC member states. A sizable share of the population lacks basic access to power, safe drinking water and improved sanitation.

Adequate infrastructure is important for economic growth and competitiveness in Africa. Inadequate infrastructure impedes faster growth. This view, endorsed by the Commission for Africa (2005), is supported by a considerable volume of economic research. A key question for policymakers is how much infrastructure development contributes to growth compared to other policy parameters. One recent study (Calderón 2009) finds that across Africa, expanding and improving infrastructure contributed almost 1 percentage point to per capita economic growth from 1990 to 2005, compared with 0.8 percentage point for macroeconomic stabilization and structural policies (Figure 1).

Trends in CEMAC countries are consistent with what is observed in Africa as a whole. Estimates from Calderón (2009) suggest that infrastructure improvements between 1995 and 2005, on average, boosted per capita growth rates by 1 percentage point largely driven by growth of mobile telephony in the region, while inadequate power infrastructure impeded growth. Infrastructure contributed most to growth in Central African countries after East African countries. However, among CEMAC countries, considerable

\footnotetext{
${ }^{1}$ By Rupa Ranganathan and Vivien Foster (World Bank).
}

Figure 1: Changes in Growth per Capita Caused by Changes in Growth Fundamentals

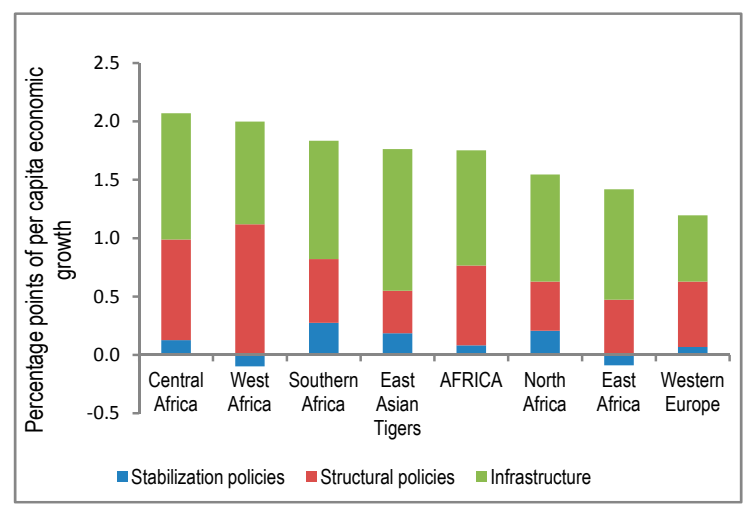

Figure 2: Infrastructure contributions to per capita growth

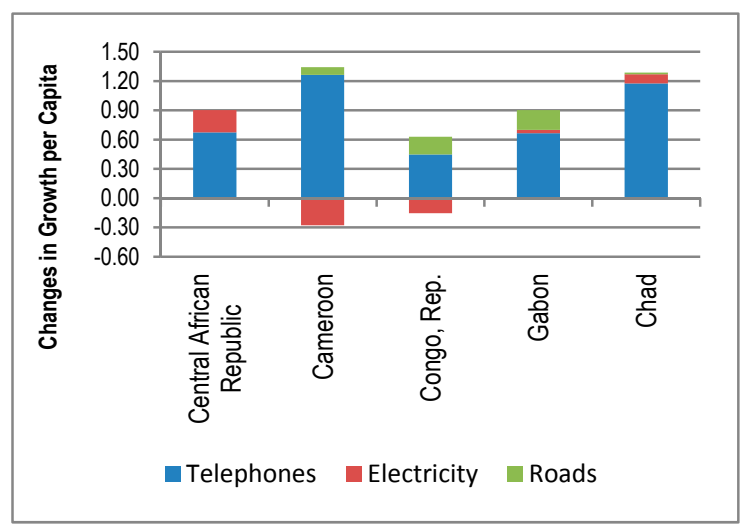

Figure 3: Potential Growth per capita due to Improvements in Infrastructure

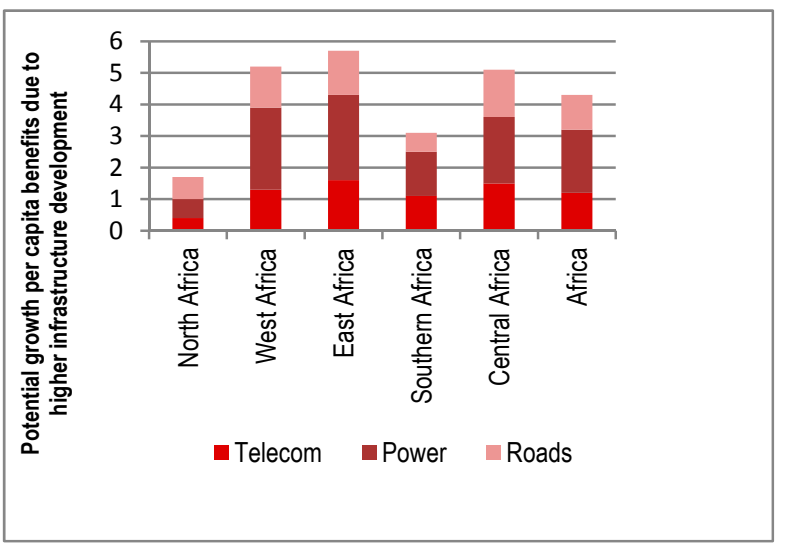

Source: Calderon, 2008 
country-specific differences exist (Figure 2), with the historic impact of infrastructure on per capita growth varying from 0.6 percentage points in the Republic of Congo to 1.2 percentage points in Cameroon. Across the board, information and communications technologies (ICT) improvements have made the largest contribution to economic growth. Power infrastructure has been a positive influence in some cases (notably Central African Republic), while holding growth back in others (Cameroon and Congo Republic).

Simulations suggest that infrastructure could contribute much more to growth than it does presently. If Central Africa's infrastructure could be upgraded to the level of the best performing country in Africa (Mauritius), the impact on per capita economic growth would be on the order of 5 percent with the greatest impact coming from the power sector followed by roads and telecom (Figure 3).

More detailed microeconomic work on the relationship between infrastructure and the performance of firms supports these macroeconomic findings for Africa. The data consistently show a strong relationship between infrastructure stocks and the output, productivity, and investment behavior of firms. An exhaustive study analyzed the entire set of investment climate surveys in Africa (Escribano, Guasch, and Peña, 2010). In African countries, particularly the low-income countries, infrastructure is a major constraint on doing business and depresses firm productivity by about 40 percent. Firms report that infrastructure contributed almost 50 percent to total factor productivity with 40 percent of the contribution coming from customs clearance and around 20 percent coming from power and water infrastructure. Firms indicated that inadequate infrastructure constrained growth. The situation is even more acute in CEMAC countries. Between 60 and 75 percent of firms in Cameroon, Chad, Republic of Congo and Gabon identify power as a major constraint to doing business; almost half the firms in Chad, Republic of Congo and Gabon identify transport as the major bottleneck.

Additionally, infrastructure is a key input for human development. Safe and convenient water supply arrests the spread of life-threatening diseases and prevents child mortality and malnutrition. Electricity powers health and education and boosts productivity of businesses. Transportation networks link local, regional, and global markets. ICT services democratize access to information, facilitate ease of communication, and reduce transport costs by conducting transactions remotely. 


\section{Benchmarking CEMAC's infrastructure}

The CEMAC region is plagued by inadequate infrastructure and pays the highest prices in the Africa region for this infrastructure. CEMAC's infrastructure performance lags its peers along several infrastructure dimensions. This is striking especially because the region experienced strong growth in the early 2000 s and accrued significant oil wealth during this time.

\begin{tabular}{|c|c|c|c|c|c|}
\hline \multicolumn{6}{|c|}{ Table 1: Infrastructure Access in the CEMAC Region } \\
\hline \multirow[b]{2}{*}{ Indicator } & \multirow[b]{2}{*}{ Units } & \multirow[b]{2}{*}{ CEMAC } & \multicolumn{3}{|c|}{ SSA Benchmarks } \\
\hline & & & LICs & $\begin{array}{l}\text { Resource } \\
\text { Rich }\end{array}$ & MICs \\
\hline $\begin{array}{l}\text { Classified road network } \\
\text { density }\end{array}$ & $\begin{array}{l}\text { Kms per } 1,000 \\
\text { people }\end{array}$ & 2.4 & 1.3 & 2.3 & 7.1 \\
\hline $\begin{array}{l}\text { Classified road network } \\
\text { in good condition }\end{array}$ & $\%$ & 32 & 35 & 29 & 48 \\
\hline $\begin{array}{l}\text { Installed generation } \\
\text { capacity }\end{array}$ & $\begin{array}{l}\text { MW per million } \\
\text { people }\end{array}$ & 16 & 20 & 43 & 799 \\
\hline Access to electricity & $\%$ of population & 30 & 33 & 46 & 50 \\
\hline Internet subscribers & Per 100 people & 2.8 & 5.69 & 11.8 & 8.94 \\
\hline $\begin{array}{l}\text { Mobile telephone } \\
\text { subscribers }\end{array}$ & Per 100 people & 28.9 & 25.58 & 37.35 & 57.33 \\
\hline Main telephone lines & Per 100 people & 0.7 & 0.8 & 0.83 & 4.78 \\
\hline Access to piped water & $\%$ population & 12 & 10.5 & 12 & 52.1 \\
\hline $\begin{array}{l}\text { Access to flush toilet or } \\
\text { septic tank }\end{array}$ & $\%$ population & 6 & 4.9 & 11.2 & 40.8 \\
\hline $\begin{array}{l}\text { Source: Africa Infrastruc } \\
\text { ICT data for } 2008 \text {; energ } \\
\text { year available in } 2000-0\end{array}$ & $\begin{array}{l}\text { Country Diagnosti } \\
\text { water data for } 2 C\end{array}$ & $\begin{array}{l}\text { Department } \\
\text { lectricity a }\end{array}$ & $\begin{array}{l}\text { nergy; } h \\
\text { for } 200\end{array}$ & $\begin{array}{l}\text { Bank IC4D } \\
\text { enchmarks }\end{array}$ & $\begin{array}{l}\text { oads an } \\
\text { for lates }\end{array}$ \\
\hline
\end{tabular}

Overall, CEMAC countries - despite their oil wealth - display infrastructure indicators on a par with other low-income countries in Africa that lack natural resource wealth. In power and ICT, CEMAC's infrastructure indicators are particularly far behind that of other resource rich countries in Africa.

Consumers in CEMAC countries pay extremely high prices for infrastructure services relative to global and African standards (Table 2). Power prices are three times those in other developing countries of the world. Road freight tariffs on average are also three times the rate of those in other developing regions. A combination of factors underlies these high costs. For example, in the power Table 2: Infrastructure Costs in the CEMAC Region

\begin{tabular}{|c|c|c|c|}
\hline & CEMAC & $\begin{array}{c}\text { Sub- } \\
\text { Saharan } \\
\text { Africa }\end{array}$ & $\begin{array}{c}\text { Other } \\
\text { Developing } \\
\text { Countries }\end{array}$ \\
\hline Power tariffs (US\$ per kilowatt-hour) & $0.10-0.30$ & $0.03-0.43$ & $0.05-0.10$ \\
\hline $\begin{array}{l}\text { Port container handling charges (US\$ per } \\
\text { TEU) }\end{array}$ & $160-260$ & $100-320$ & $80-150^{*}$ \\
\hline Road freight tariffs (US\$ per ton-kilometer) & 0.13 & $0.04-0.13$ & $0.01-0.04$ \\
\hline Mobile telephony (US\$ per basket per month) & 15.1 & $2.6-21$ & 9.9 \\
\hline Internet dial-up service (US\$ per month) & 68.0 & $6.7-148$ & 11 \\
\hline
\end{tabular}
sector, costs of power generation are genuinely higher in many African countries because of the small scale of power systems and the reliance on expensive diesel-based generation technology, with costs that can run nearly three times as high as those of larger hydro-based power systems in Africa. High costs of road transport in the CEMAC region are also due to the presence of 
cartels and restrictive regulation of the trucking industry leading to exceptionally high profit margins. The expensive costs of ICT services in the CEMAC region can be explained by the small number of countries connected to the submarine cable or absence of competition in international gateways even where countries are connected.

The poor quality of infrastructure and high prices can be attributed to a combination of "hardware" issues and "software" issues. The software challenges pertain to regulatory obstacles that curtail the efficiency of the infrastructure sectors. The regulatory challenges are major culprits that add significantly to infrastructure costs and constrain growth and trade. Addressing infrastructure constraints in Africa requires not only upgrading of the stock but also correction of institutional hurdles that stymie the sector.

\section{Financing CEMAC's infrastructure}

Redressing the infrastructure gaps in the CEMAC region over the next 10 years requires significant spending and a serious and consistent effort to minimize inefficiencies that encumber the sectors. Addressing CEMAC's infrastructure would require annual spending of $\$ 4.7$ billion or 10 percent of GDP to meet basic infrastructure thresholds. The region already spends an annual average of US\$2.4 billion annually or approximately 5.2 percent of GDP — split almost evenly between capital and operating expenditures - on infrastructure. However, a staggering $\$ 1.2$ billion a year is lost owing to inefficiencies related to incorrect pricing of infrastructure services, under collection of bills or losses in distribution. If the region were to fully eliminate losses owing to inefficiencies, the funding gap for infrastructure would fall to $\$ 1.1$ billion a year for the entire region. A critical issue would be to ensure that expenditure on infrastructure is productive and well managed.

\section{References}

Calderón, César, 2009, "Infrastructure and Growth in Africa," World Bank Policy Research Working Paper 4914 (Washington: World Bank).

Escribano, Alvaro, J., Luis Guasch, and Jorge Peña, 2010, “Assessing the Impact of Infrastructure Quality on Firm Productivity in Africa” World Bank Policy Research Working Paper 5191(Washington: World Bank). 


\section{APPENDIX 4. Determinants of Non-Oil Growth in the CFA-Zone Oil-Producing Countries ${ }^{1}$}

\section{INTRODUCTION}

Non-oil growth in the CFA oil-exporting countries has been lackluster despite their great natural resource wealth. This is perhaps unsurprising given that only a few resource-rich countries have succeeded in diversifying their economies (Coxhead, 2007; Gelb and Grasmann, 2010). This often-cited "resource curse" is frequently attributed to three main factors: Dutch disease stemming from real effective exchange rate appreciation; high volatility of oil- and mineralrelated revenues; and institutional weaknesses, particularly in governance and transparency.

In this paper we study the key determinants of non-oil growth in the oil-producing countries of the CFA zone and explore to what extent these countries differ from countries with comparable levels of development that do not depend on nonrenewable resources.

Estimation results using a panel of 38 low-income countries (LIC) and CFA zone oil exporters are broadly aligned with the theoretical predictions. ${ }^{2}$ Though real exchange rate appreciation is found to have negatively affected growth in all countries from 1985 to 2008, what distinguishes the oil producers of the CFA zone is the failure of public and private investment to boost non-oil growth.

\section{EMPIRICAL INVESTIGATION}

Tabova and Baker (2011) showed that productive use of public resources and the efficiency of investment are key ingredients for non-oil growth, with the real exchange rate affecting growth indirectly through the role it plays in the allocation of capital across sectors. In what follows we test these theoretical predictions for the CFA oil exporting countries and explore to what extent these countries differ from countries with comparable levels of development that are not highly dependent on oil or mineral resources.

We estimate a growth equation using a panel with country and time fixed effects:

\footnotetext{
${ }^{1}$ By A. Tabova and C. Baker.

${ }^{2}$ The group of low-income countries comprises Benin, Burkina Faso, Central African Republic, Guinea-Bissau, Mali, Niger, Senegal, Togo, Burundi, Comoros, Ethiopia, Gambia, Ghana, Guinea, Kenya, Madagascar, Malawi, Mauritania, Mozambique, Rwanda, Sierra Leone, Tanzania, Uganda, Zambia, Bangladesh, Cambodia, Lao P.D.R., Vietnam, Tajikistan, Uzbekistan, and Haiti. The group of CFA oil exporters includes Cameroon, Chad, Congo (Republic of), Cote d'Ivoire, and Gabon.
} 


$$
g_{i t}^{n}=\alpha_{0}+\alpha_{1} \ln R_{i t}+\alpha_{\mathbf{2}} \mathbf{X}_{i t}+\alpha_{3} D^{C F A o i l} \mathbf{X}_{i t}+\alpha_{t}+\alpha_{i}+u_{i t}
$$

where $g_{i t}^{n}$ is real non-oil GDP growth and $X_{i t}$ is a vector of standard growth determinants such as initial income, investment share of output, share of government consumption in output, terms of trade, and a measure of openness to trade. $D^{C F A \text { oil }}$ is a dummy variable for the CFA oil exporters. ${ }^{3}$ The interaction term $D^{C F A \text { oil }} \mathbf{X}_{i t}$ captures whether and how CFA oil exporters differ from the rest of the sample with regard to the way the standard growth determinants affect nonoil growth. The net impact of $X_{i t}$ on growth for the CFA oil exporters is captured by $\alpha_{2}+\alpha_{3}$. The fixed effects framework implies that we estimate changes in the explanatory variables on changes in growth rates within countries. The time and country fixed effects are captured by the terms $\alpha_{t}$ and $\alpha_{i}$, respectively.

In equation (1) $R_{\text {it }}$ is a measure of the real exchange rate. Following Rodrik (2008) and Berg and Miao (2010), we include $R_{\text {it }}$ directly in the non-oil GDP growth equation. Following Rodrik (2008), Delechat and others (2009), and Berg and Miao (2010), we define $R_{i t}$ as the deviation of the actual real exchange rate from its PPP value, adjusted for the effects of per capita income on the real exchange rate. The exchange rate over/under-valuation is then the residual in a regression of the real exchange rate on per capita income: $\epsilon_{i t}^{p p p}$.

$$
\ln \mathrm{RER}_{i t}=\alpha_{0}+\alpha_{1} \ln y_{i t}+\alpha_{t}+\epsilon_{i t}^{p p p}
$$

This measure has the advantage that it is directly comparable across countries. The dependent variable $\ln \mathrm{RER}_{i t}$ in (2) is the log of the ratio of the market exchange rate to the PPP conversion factor; the log of per capita GDP ln $y_{i t}$ accounts for the Balassa-Samuelson effect. Subscript $t$ denotes the 3-year average period, and $i$ denotes the country. The set of time fixed effects is captured by $\alpha_{t}$. We follow the literature and estimate equation (2) for 181 countries that have data available for the entire period (see Rodrik, 2008; Delechat and others, 2009).

Turning to the estimation of equation (1), the dependent variable is real non-oil GDP growth, measured as log difference. We include initial income, measured as the log of real GDP per capita in constant 2000 US dollars, to control for the Balassa-Samuelson effect. Openness to trade is defined as (Exports + Imports)/GDP, government consumption is measured as public consumption expenditure as a share of total GDP, and investment refers to gross fixed capital formation as a share of total GDP. The source of data is WEO, the period covered is 1985-2008,

\footnotetext{
${ }^{3}$ We do not estimate the direct impact of market weaknesses on growth because as the theoretical model above shows, these will manifest themselves through the effectiveness of investment in spurring growth.
} 
and all variables are three-year averages as is common in the literature to account for business cycle fluctuations.

Ideally, we would assess the role of the stock of capital on non-oil growth, which would be aligned with the theoretical model presented in the previous section. Constructing capital stocks, however, is nontrivial, especially for LICs and postconflict countries, and requires a number of important assumptions regarding initial capital stocks, the level and time profile of depreciation rates, and the depreciation method. ${ }^{4}$ Rather than constructing stock of capital across countries we follow the empirical growth literature that uses instead investment rates (see for example Ramey and Ramey, 1995; Miao and Berg, 2010). Consequently, our empirical estimates do not explicitly take into account the efficiency of converting investment into capital.

As control groups to the CEMAC oil exporters we use (i) the CFA non-oil exporters and (ii) a sample of select low-income countries; in total, the final sample contains 38 countries (excluding Equatorial Guinea) and 270 observations. ${ }^{5}$ While for the baseline specifications we use $\ln R_{i t} \equiv \epsilon_{i t}^{p p p}$, as a robustness check we also use the log of the real effective exchange rate $\mathrm{REER}_{i t}$ as an alternative measure of the exchange rate.

As a starting point, Table 1 column 1 reports the results of a standard growth specification for the entire sample of 38 countries that does not distinguish among the three country groups. The specification is therefore a simplification of equation (1) where we ignore the interaction terms $D^{C F A \text { oil }} \mathbf{X}_{i t}$. It closely follows Berg and Miao (2010) and the results confirm their findings, both in terms of magnitude and significance of the coefficients. Our results are also consistent with recent empirical studies that have documented that for developing countries exchange rate overvaluations are associated with lower growth rates (Rodrik, 2008; Berg and Miao, 2010). The estimates for the exchange rate measures suggest that a 10 percent overvaluation is associated with a 0.25 percentage point lower growth rate. The estimates for investment and government consumption imply that a 1 percentage point increase in the share of investment in total GDP is associated with a 0.127 percentage point higher growth, while a 1 percentage point increase in the share of government consumption in total GDP is associated with a 0.076 percentage point

\footnotetext{
${ }^{4}$ See, for example, Klenow and Rodriguez-Clare's (1997) analysis of the neoclassical growth model, in which they measure capital stocks by accumulating investment data in the Penn World Tables.

${ }^{5}$ The group of CFA oil exporters includes Cameroon, Chad, Congo (Republic of), Cote d'Ivoire, and Gabon. The group of CFA non-oil exporters includes Benin, Burkina Faso, Central African Republic, Guinea-Bissau, Mali, Niger, Senegal, and Togo. The group of low-income countries (LICs) includes Burundi, Comoros, Ethiopia, Gambia, Ghana, Guinea, Kenya, Madagascar, Malawi, Mauritania, Mozambique, Rwanda, Sierra Leone, Tanzania, Uganda, Zambia, Bangladesh, Cambodia, Lao P.D.R., Vietnam, Tajikistan, Uzbekistan, and Haiti.
} 
lower growth. Although it is common in the literature to include government consumption or investment shares in GDP growth regressions, the endogeneity problem can be non-trivial and results may reflect to a certain extent reverse causality (see for example Berg and Miao, 2010). The same issue applies to the inclusion of the real exchange rate in the growth regression. One might address this concern by a dynamic panel estimation using GMM (see Arellano and Bond, 1991).

Reassured by findings for the panel as a whole that are consistent with the empirical findings in the literature, we proceed to investigate the factors that have led to lower non-oil growth in the CFA zone oil-exporting countries. The results in Table 1, column 2, imply that although on average investment is positively and significantly associated with growth for the sample as a whole, for the CFA oil exporters' investment is not related to growth in a statistically significant way. The coefficient on the interaction term in column 2 shows that for the CFA oil-exporting countries the impact of investment as a share of GDP on non-oil growth differs significantly from the impact it has for the rest of the countries in the sample. The net impact for the CFA oil exporters $\left(\alpha_{2}+\alpha_{3}\right)$ is -0.005 and a Wald test shows that this net coefficient is not statistically significant. The results in column 3 show that the lack of a significant relation between investment and non-oil growth for the CFA oil exporters is also evident when we control separately for the CFA non-oil countries. Similar to the results in column 2, the net effect of investment for the CFA oil exporters -0.004 and a Wald test shows it is not statistically different from zero. Column 3 shows that for the group of CFA non-oil exporters the net effect of investment is positive and significant at the 1 percent level, although at 0.07 it is much lower than the estimate for the average low-income country in the sample.

Next, as a robustness check, we use the log of the real effective exchange rate $\mathrm{REER}_{i t}$ as a measure of the exchange rate. Table 2 shows that the results do not change and are therefore robust to alternative measures of the exchange rate. The estimates for the exchange rate measures suggest that a 10 percent overvaluation or a 10 percent increase in the real effective exchange rate (REER) is associated with a 0.3 percentage point, lower growth rate.

Turning to the composition of investment, because the oil revenues accrue to the governments of the oil-exporting countries in the CFA zone, and public investment constitutes the majority of total investment in these countries, we disaggregate investment into private and public investment as a share of GDP. ${ }^{6}$ The results are shown in Table 3.

\footnotetext{
${ }^{6}$ Public investment is gross public fixed capital formation as a share of total GDP; private investment is gross private fixed capital formation as a share of total GDP. While much of the private investment is in the oil sector, public investment is in infrastructure and residential construction.
} 
For the sample as a whole, the positive association between both public and private investment and growth is preserved (Table 3, column 1). However, for the CFA oil exporters we fail to detect any significant association between non-oil growth and either public or private investment: the net coefficients are -0.088 and 0.014 , respectively, and a Wald test indicates that neither is statistically significant from zero (Text Table 1). The insignificant coefficient on the interaction term of the CFA non-oil exporters dummy with public investment means that the relation between public investment and growth in these countries does not differ from that found for the average low-income country in the sample (0.19).

Text Table 1. Impact of investment on non-oil growth

\begin{tabular}{|c|c|c|c|c|c|c|}
\hline & \multicolumn{2}{|c|}{ Total investment } & \multicolumn{2}{|c|}{ Public investment } & \multicolumn{2}{|c|}{ Private investment } \\
\hline & Coefficient & $\begin{array}{c}\text { p-value } \\
\text { (Wald test) }\end{array}$ & Coefficient & $\begin{array}{c}\text { p-value } \\
\text { (Wald test) }\end{array}$ & Coefficient & $\begin{array}{c}\text { p-value } \\
\text { (Wald test) }\end{array}$ \\
\hline \multirow{2}{*}{ Select LICs } & $0.211^{* *}$ & 0.018 & $0.191^{*}$ & 0.069 & $0.223^{* *}$ & 0.032 \\
\hline & \multicolumn{2}{|c|}{ positive and significant } & \multicolumn{2}{|c|}{ positive and significant } & \multicolumn{2}{|c|}{ positive and significant } \\
\hline \multirow{2}{*}{$\begin{array}{l}\text { CFA zone non- } \\
\text { oil exporters }\end{array}$} & $0.068^{* * *}$ & 0.008 & $0.180^{*}$ & 0.03 & 0.017 & 0.697 \\
\hline & \multicolumn{2}{|c|}{ positive and significant } & \multicolumn{2}{|c|}{ positive and significant } & \multicolumn{2}{|c|}{ positive but insignificant } \\
\hline \multirow{2}{*}{$\begin{array}{l}\text { CFA zone oil } \\
\text { exporters }\end{array}$} & -0.004 & 0.899 & -0.088 & 0.516 & 0.014 & 0.612 \\
\hline & \multicolumn{2}{|c|}{ negative but insignificant } & \multicolumn{2}{|c|}{ negative but insignificant } & \multicolumn{2}{|c|}{ positive but insignificant } \\
\hline
\end{tabular}

To address the importance of the exchange rate and the recent empirical literature on the role of the exchange rate for GDP growth in developing countries, we also estimate all the specifications including an interaction term with either measure of the exchange rate (undervaluation index or the REER). This allows us to see whether the real exchange rate affects growth in the three country groups in a significantly different way. The results (not shown) indicate that there is no statistically significant difference in the way the real exchange rate is associated with GDP growth in the three country groups.

Turning to investment efficiency, in a recent study Dabla-Norris and others (2011) construct an index of the efficiency of the public investment management process for 71 developing countries. The efficiency of public investment is proxied by aggregate indicators of the quality and efficiency of four crucial stages of the investment process: investment project appraisal, selection, implementation, and evaluation. Although the focus of this index is on the quality of the process for managing public investments and the index is not available for all countries in our empirical investigation, it nevertheless provides a useful benchmark for our empirical findings. In terms of country comparisons, our results are broadly aligned with the rankings based on this new index. Notably, all but one of the CFA oil-exporting countries for which the index is available rank among the weakest performers. 


\section{CONCLUSION}

Using a panel of 38 countries comprising LICs and CFA zone oil exporters, we find that when controlling for the real effective exchange rate, there is a failure of investment in oil-producing countries of the CFA zone in spurring growth. For LICs outside of the CFA zone, private investment is found to have a fairly large, positive and statistically significant impact on growth, while public investment has a somewhat weaker impact on growth. For CFA zone non-oil producers, the impact of public investment on growth is lower than in other LICs but positive and significant. In contrast, for CFA zone oil producers, public investment is found to have no impact on growth. For both groups within the CFA zone, the impact of private investment is not statistically different from zero.

There are many reasons why investment may not raise non-oil growth in the oil exporting countries of the CFA zone. First, investment itself may be less efficient owing to project selection and/or capacity constraints related to project appraisal, implementation and monitoring. Second, it is likely that the necessary conditions for public investment to spur private sector activity are not in place. Such conditions include basic infrastructure (above a required threshold level), an enabling business environment and strong institutions and governance. These conclusions are supported by our theoretical model which demonstrates that public goods are growth enhancing and weak institutions and market imperfections impede growth. 
Table 1. Growth and Total Investment: Estimation Results

\begin{tabular}{|c|c|c|c|}
\hline & $(1)$ & $(2)$ & (3) \\
\hline Non-oil growth (lagged) & $\begin{array}{l}0.007 \\
(0.06)\end{array}$ & $\begin{array}{l}-0.005 \\
(0.06)\end{array}$ & $\begin{array}{l}-0.010 \\
(0.06)\end{array}$ \\
\hline UNDERVAL (ln) & $\begin{array}{c}0.025^{* *} \\
(0.01)\end{array}$ & $\begin{array}{c}0.025^{* *} \\
(0.01)\end{array}$ & $\begin{array}{c}0.028 * * * \\
(0.01)\end{array}$ \\
\hline Initial income $(\ln )$ & $\begin{array}{c}-0.078 * * * \\
(0.02)\end{array}$ & $\begin{array}{c}-0.078 * * * \\
(0.02)\end{array}$ & $\begin{array}{c}-0.081 * * * \\
(0.02)\end{array}$ \\
\hline Terms of trade $(\ln )$ & $\begin{array}{l}0.007 \\
(0.01)\end{array}$ & $\begin{array}{l}0.009 \\
(0.01)\end{array}$ & $\begin{array}{l}0.012 \\
(0.01)\end{array}$ \\
\hline Openness & $\begin{array}{c}0.004 \\
(0.02)\end{array}$ & $\begin{array}{l}0.007 \\
(0.02)\end{array}$ & $\begin{array}{c}0.003 \\
(0.02)\end{array}$ \\
\hline Investment & $\begin{array}{c}0.127 * * * \\
(0.04)\end{array}$ & $\begin{array}{c}0.154 * * * \\
(0.05)\end{array}$ & $\begin{array}{c}0.211 * * * \\
(0.09)\end{array}$ \\
\hline Gov. Consumption & $\begin{array}{c}-0.076^{* *} \\
(0.04)\end{array}$ & $\begin{array}{c}-0.095 * * \\
(0.04)\end{array}$ & $\begin{array}{c}-0.134 * * \\
(0.07)\end{array}$ \\
\hline $\mathrm{CFA}^{\mathrm{oil} *}$ Investment & & $\begin{array}{c}-0.159 * * * \\
(0.04)\end{array}$ & $\begin{array}{c}-0.215^{* * *} \\
(0.08)\end{array}$ \\
\hline $\mathrm{CFA}^{\text {non-oil } *}$ Investment & & & $\begin{array}{c}-0.143^{*} \\
(0.09)\end{array}$ \\
\hline $\begin{array}{l}\text { Adjusted } \mathrm{R}^{2} \\
\text { Observations }\end{array}$ & $\begin{array}{l}0.28 \\
270 \\
\end{array}$ & $\begin{array}{l}0.29 \\
270 \\
\end{array}$ & $\begin{array}{l}0.30 \\
270 \\
\end{array}$ \\
\hline
\end{tabular}

Dependent variable: real non-oil GDP growth. Panel estimation with time and country fixed effects. Heteroscedasticity-consistent standard errors in parentheses. $* * *(1 \%)$, $* *(5 \%), *(10 \%)$. 
Table 2. Growth and Total Investment Robustness Check: Estimation Results Using the Real Effective Exchange Rate (REER) versus the PPP Undervaluation Index

\begin{tabular}{|c|c|c|}
\hline & $(1)$ & $(2)$ \\
\hline Non-oil growth (lagged) & $\begin{array}{l}-0.024 \\
(0.07)\end{array}$ & $\begin{array}{l}-0.010 \\
(0.06)\end{array}$ \\
\hline REER (ln) & $\begin{array}{c}-0.027 * * * \\
(0.01)\end{array}$ & \\
\hline UNDERVAL (ln) & & $\begin{array}{c}0.028 * * * \\
(0.01)\end{array}$ \\
\hline Initial income (ln) & $\begin{array}{c}-0.080 * * * \\
(0.02)\end{array}$ & $\begin{array}{c}-0.081 * * * \\
(0.02)\end{array}$ \\
\hline Terms of trade $(\ln )$ & $\begin{array}{l}0.010 \\
(0.01)\end{array}$ & $\begin{array}{l}0.012 \\
(0.01)\end{array}$ \\
\hline Openness & $\begin{array}{l}0.001 \\
(0.02)\end{array}$ & $\begin{array}{l}0.003 \\
(0.02)\end{array}$ \\
\hline Investment & $\begin{array}{c}0.206 * * * \\
(0.07)\end{array}$ & $\begin{array}{c}0.211 * * * \\
(0.09)\end{array}$ \\
\hline Gov. Consumption & $\begin{array}{c}-0.131 * * \\
(0.05)\end{array}$ & $\begin{array}{c}-0.134 * * \\
(0.07)\end{array}$ \\
\hline $\mathrm{CFA}^{\text {oil }} *$ Investment & $\begin{array}{c}-0.211 * * * \\
(0.06)\end{array}$ & $\begin{array}{c}-0.215^{* * *} \\
(0.08)\end{array}$ \\
\hline $\mathrm{CFA}^{\text {non-oil }} *$ Investment & $\begin{array}{c}-0.141 * \\
(0.08)\end{array}$ & $\begin{array}{c}-0.143 * \\
(0.09)\end{array}$ \\
\hline $\begin{array}{l}\text { Adjusted } \mathrm{R}^{2} \\
\text { Observations }\end{array}$ & $\begin{array}{l}0.31 \\
270\end{array}$ & $\begin{array}{l}0.30 \\
270\end{array}$ \\
\hline
\end{tabular}

Dependent variable: real non-oil GDP growth. Panel estimation with time and country fixed effects. Heteroscedasticity-consistent standard errors in parentheses. $* * *(1 \%), * *(5 \%), *(10 \%)$. 
Table 3. Growth and Investment: Estimation Results When Investment Is Disaggregated into Public and Private Investment

\begin{tabular}{|c|c|c|}
\hline & $(1)$ & (2) \\
\hline Non-oil growth (lagged) & $\begin{array}{l}-0.002 \\
(0.07)\end{array}$ & $\begin{array}{l}-0.018 \\
(0.07)\end{array}$ \\
\hline UNDERVAL (ln) & $\begin{array}{c}0.026 * * \\
(0.01)\end{array}$ & $\begin{array}{c}0.029 * * \\
(0.01)\end{array}$ \\
\hline Initial income (ln) & $\begin{array}{c}-0.078 * * * \\
(0.02)\end{array}$ & $\begin{array}{c}-0.081 * * * \\
(0.02)\end{array}$ \\
\hline Terms of trade $(\ln )$ & $\begin{array}{l}0.008 \\
(0.01)\end{array}$ & $\begin{array}{l}0.013 * \\
(0.01)\end{array}$ \\
\hline Openness & $\begin{array}{l}0.003 \\
(0.02)\end{array}$ & $\begin{array}{l}0.003 \\
(0.02)\end{array}$ \\
\hline Private Investment & $\begin{array}{c}0.129 * * \\
(0.05)\end{array}$ & $\begin{array}{c}0.223 * * \\
(0.10)\end{array}$ \\
\hline Public Investment & $\begin{array}{l}0.117^{*} \\
(0.06)\end{array}$ & $\begin{array}{l}0.191 * \\
(0.10)\end{array}$ \\
\hline Government Consumption & $\begin{array}{c}-0.078 * \\
(0.04)\end{array}$ & $\begin{array}{c}-0.145^{*} \\
(0.07)\end{array}$ \\
\hline $\mathrm{CFA}^{\text {oil }} *$ Private Investment & & $\begin{array}{c}-0.209 * * \\
(0.09)\end{array}$ \\
\hline $\mathrm{CFA}^{\text {oil }} *$ Public Investment & & $\begin{array}{c}-0.279^{*} \\
(0.16)\end{array}$ \\
\hline $\mathrm{CFA}^{\text {non-oil }} *$ Private Investment & & $\begin{array}{c}-0.206^{*} \\
(0.12)\end{array}$ \\
\hline $\mathrm{CFA}^{\text {non-oil }} *$ Public Investment & & $\begin{array}{l}-0.011 \\
(0.13)\end{array}$ \\
\hline $\begin{array}{l}\text { Adjusted } \mathrm{R}^{2} \\
\text { Observations }\end{array}$ & $\begin{array}{l}0.28 \\
270\end{array}$ & $\begin{array}{l}0.30 \\
270\end{array}$ \\
\hline
\end{tabular}

Dependent variable: real non-oil GDP growth. Panel with time and country fixed effects. Heteroscedasticity-consistent standard errors in parentheses. $* * *(1 \%), * *(5 \%), *(10 \%)$. 


\section{References}

Arellano, M., and S. Bond, 1991, "Some tests of specification for panel data: Monte Carlo evidence and an application to employment equations," Review of Economic Studies, Vol. 58, pp. 277-297.

Berg, A. and Y. Miao, 2010, “The Real Exchange Rate and Growth Revisited: The Washington Consensus Strikes Back?” IMF Working Paper WP/10/58 (Washington: International Monetary Fund).

Calderon, C. and L. Serven, 2008, "Infrastructure and Economic Development in Sub-Saharan Africa," World Bank Policy Research Working Paper No. 4712 (Washington: World Bank).

Coxhead, I., 2007, "A New Resource Curse? Impacts of China's Boom on Comparative Advantage and Resource Dependence in Southeast Asia". World Development 35: 7, pp 1099-1119.

Dabla-Norris, E., J. Brumby, A. Kyobe, Z. Mills, and C. Papageorgiou, 2011, "Investing in Public Investment: An Index of Public Investment Efficiency". IMF Working Paper $\mathrm{WP} / 11 / 37$.

Delechat, C., G. Ramirez, S. Wang, and J. Wakeman-Linn, 2009, “Sub-Saharan Africa's Integration in the Global Financial Markets" IMF Working Paper WP/09/114.

Gelb, A. and S. Grasmann, 2010, "How Should Oil Exporters Spend their Rents?” CGD Working Paper 221 (Washington: Center for Global Development).

Klenow, Peter J. and Andrés Rodríguez-Clare, 1997, “The Neoclassical Revival in Growth Economics: Has it Gone too Far?" NBER Macroeconomics Annual 1997. Cambridge, MA: MIT Press.

Ramey, G. and V. A. Ramey, 1995, "Cross-Country Evidence on the Link between Volatility and Growth”. The American Economic Review, Vol. 85, No. 5, pp. 1138-1151.

Rodrik, D., 2008, “The Real Exchange Rate and Economic Growth”. Brookings Papers on Economic Activity.

Tabova, A., and C. Baker, 2011, "Determinants of Non-oil GDP Growth in the CFA-Zone Oil Producing Countries: How Do They Differ?” IMF Working Paper WP/11/233. 


\section{APPENDIX 5. Relations of CEMAC Member Countries and the Fund}

\section{Membership Status}

1. Cameroon, Central African Republic, Chad, Republic of Congo, and Gabon joined the IMF in 1963 Equatorial Guinea joined in 1969. The region accepted Article VIII on June 1, 1996.

\section{Relations of the CEMAC Member Countries and the Fund}

2. Cameroon: On July 14, the Board concluded the 2010 Article IV consultation. It also discussed the Second Poverty Reduction Strategy Paper (PRSP) and the Joint IDA-IMF Staff Advisory Note. The 2011 Article IV consultation discussion by the Board is scheduled for June 24. Cameroon is on a 12-month consultation cycle.

3. Central African Republic (C.A.R.): The Executive Board approved a three-year PRGF arrangement on December 22, 2006 in an amount equivalent to SDR 36.2 million (about US\$58.4 million). The second review was completed on June 18, 2008, and access was increased by SDR 8.355 million (about US\$13.5 million) to help the country address the impact of rising food and oil prices. Access was again increased by SDR 25.065 million, to a total of 125 percent of quota, in the fourth review on June 29, 2009. On the same day, C.A.R. also reached the completion point under the enhanced HIPC initiative. The last Article IV consultation was on December 4, 2009, together with the fifth PRGF review, and the sixth and last review was concluded on August 25, 2010. The authorities have expressed their interest in a successor arrangement under the Extended Credit Facility (ECF).

4. Chad: The last financial arrangement, a PRGF, expired in May 2008 with no review completed. A 2009 Staff-Monitored Program (SMP) went off-track due to sizeable overruns on security spending and investment projects. The authorities have expressed interest in discussing an SMP covering the latter half of 2011. The last Article IV consultation was completed on June 17, 2010. Chad is on a 12-month consultation cycle.

5. Congo: The Executive Board approved a three-year PRGF arrangement for Congo in an amount equivalent to SDR 8.5 million (about US\$13.4 million) in December 2008. The country reached the Decision Point under the enhanced HIPC initiative on March 8, 2006. The last Article IV consultation and Fourth review under the ECF were concluded on January 19, 2011. Congo is on a 24-month consultation cycle

6. Equatorial Guinea: The last financial arrangement, an ESAF, expired in 1996.

Equatorial Guinea is not expected to seek Fund financial assistance over the next few years. The country is not eligible for assistance under the HIPC initiative. The last Article IV consultation was concluded on April 22, 2011. Equatorial Guinea is on a 12-month consultation cycle. 
7. Gabon: The three-year SBA for about US\$118 million expired in May 2010, with only the first three reviews completed. Recurrent fiscal slippages made it difficult to sustain the Fundsupported program. Gabon is not eligible for assistance under the HIPC initiative. The last Article IV consultation was concluded on February 18, 2011. Gabon is on a 12-month consultation cycle.

\section{Safeguards Assessments}

8. The Bank of the Central African States (BEAC) is the regional central bank of the Central African States. The most recent safeguards assessment of the BEAC was completed on July 6, 2009. The findings of this assessment indicated that implementation of previous safeguards recommendations on financial reporting, internal audit, and internal control was limited, and that the changing risk profile of the BEAC foreign exchange holdings required further actions to strengthen safeguards at the BEAC. Subsequent to revelation of Paris office fraud, a series of initial measures and longer term reforms was agreed between the IMF and BEAC in order to continue with country programs. BEAC adopted an action plan for 2010 with the aim of reforming its own governance, and strengthening key safeguards. Implementation delays and additional safeguard concerns raised in the first special audit triggered a suspension of Fund disbursements to CEMAC countries from June through early August 2010, after which they resumed. A recent safeguards monitoring mission has identified a new series of rolling benchmarks to address outstanding safeguards concerns going forward.

\section{Exchange System}

9. The regional currency is the CFA franc. From 1948 to 1999, it was pegged to the French franc. Since the euro was introduced in 1999, it has been pegged to the euro at the rate of CFAF 655.957 per euro.

\section{Article IV Consultation}

10. Following an Executive Board decision in January 2006, discussions with monetary unions have been formalized and are part of the Article IV consultations with member countries. The discussions reported here are thus in relation with Article IV consultations with the six CEMAC member countries. The Executive Board concluded the last Article IV consultation with the CEMAC on November 13, 2009. Such consultations are held on a 12-month cycle.

\section{FSAP Participation and ROSCs}

11. The first regional Financial Sector Assessment Program (FSAP) was carried out JanuaryMarch 2006. Regional Reports on Observance of Standards and Codes (ROSCs) were done in the areas of monetary and financial policy transparency, banking supervision, and anti-money laundering and combating the financing of terrorism (AML/CFT) in June 2006. 


\section{Technical Assistance to BEAC}

Since May 2011: MCM resident general advisor to the Governor of the BEAC, Didier Casier, on governance, accounting and internal controls

March, April, May 2011: MCM experts visits on accounting, reserve management and banking supervision

January 2011: MCM TA mission to discuss MCM TA in the areas of governance, internal audit and accounting, monetary policy and research, reserve management, and banking supervision with BEAC and COBAC management and senior staff

October-November 2010: MCM TA mission to discuss TA program to strengthen BEAC and COBAC

July 2009: MCM mission with two experts on regional public debt market development.

December 2008: MCM mission with three experts (including resident advisor from AfritacCentral) on reserve management, research, and regional public debt market.

Since November 2008: MCM resident advisor, Mr. Emmanuel Rocher (on secondment from the Bank of France), in public debt management.

April, June, September, and November 2009: Visits by short-term expert Mr. Daniel Trimoulla (formerly from the Bank of France) and by Mr. Bernard Sivan (formerly from the Bank of France; September visit) in banking supervision.

December 2007: STA participation in BEAC's workshop on monetary statistics.

July 2007: Visit by MCM experts on issues regarding the BEAC's management of its foreign assets.

2006-March 2007: Continuation of visits by MCM experts on banking supervision, payments and settlements systems, and internal audit and accounting.

2000-2005: Visits by MFD experts on banking supervision, payments and settlements systems and internal audit.

2001-2004: Two MFD expert visits and one mission on payments systems.

2002-present: Visits by MFD foreign exchange reserve management experts. 
2004: MFD AMLT and CFT advisor.

2005: MFD mission on internal audit.

2002: STA participation in BEAC's workshop in monetary statistics.

2001, 2004: IMF safeguards assessments.

2001: STA mission on monetary and financial statistics (preparation of the IFS page for CEMAC). 


\section{INTERNATIONAL MONETARY FUND}

EXTERNAL

Public Information Notice

RELATIONS

DEPARTMENT

Public Information Notice (PIN) No. 11/138

International Monetary Fund

FOR IMMEDIATE RELEASE

$70019^{\text {th }}$ Street, NW

November 11, 2011

Washington, D. C. 20431 USA

\section{IMF Executive Board Concludes 2011 Discussion on Common Policies of Member Countries of the Central African Economic and Monetary Community}

On July 20, 2011, the Executive Board of the International Monetary Fund (IMF) concluded the annual discussions on Common Policies of Member Countries with the Central African Economic and Monetary Community (CEMAC). ${ }^{1}$

\section{Background}

The CEMAC has earned significant revenues from oil production in past decades, but faces substantial growth and development challenges. Five of the six CEMAC countries are oil producers; oil accounts for about 45 percent of regional gross domestic product (GDP) and 90 percent of total exports. Oil revenue, channeled through government spending, is the main driver of economic activity, but volatile oil prices and procyclical fiscal policy have caused boom and bust cycles. Spending out of oil wealth has not led to more inclusive growth. Against the backdrop of high inequality, poverty and unemployment remain widespread, and it is unlikely the region will meet the Millennium Development Goals by 2015.

\footnotetext{
${ }^{1}$ Under Article IV of the IMF's Articles of Agreement, the IMF holds bilateral discussions with members, usually every year. A staff team visits the country, collects economic and financial information, and discusses with officials the country's economic developments and policies. On return to headquarters, the staff prepares a report, which forms the basis for discussion by the Executive Board. At the conclusion of the discussion, the Managing Director, as Chairman of the Board, summarizes the views of Executive Directors, and this summary is transmitted to the country's authorities. An explanation of any qualifiers used in summings up can be found here: http://www.imf.org/external/np/sec/misc/qualifiers.htm.
} 
The CEMAC is recovering from the global financial crisis, although growth has not returned to pre-crisis levels and continues to lag the average in Sub-saharan Africa. Although higher than the West African Economic and Monetary Union average, the region's inflation has been contained largely because higher international oil prices have not been passed through to domestic prices. Good harvests in some CEMAC countries have also helped contain inflation. High commodity prices and healthy export demand have improved the current account and fiscal balances, but the non-oil primary fiscal deficit has widened, reflecting a scaling up of public investment. The outlook is generally positive with activity expected to remain robust, supported by public investment and commodity exports. The foremost downside risk is a decline in commodity prices, especially oil, given a heavy dependence on commodity exports.

Compliance with regional convergence criteria improved in 2010 with 6 violations in 2010, down from 9 in 2009. All the CEMAC countries satisfied the criteria on public debt and the non-accumulation of arrears, while four missed the requirement of a nonnegative basic fiscal balance and two missed the inflation threshold.

The fixed exchange rate system is backed by gross international reserves which currently stand at about 4.5 months of total imports (100 percent of broad money) and are projected to stabilize at about 4 months of total imports by 2015. The union's reserves position could strengthen further if oil prices are higher than projected in the medium term.

\section{Executive Board Assessment}

Executive Directors welcomed the region's economic recovery from the global financial crisis and its overall positive outlook. Directors noted, however, that the recovery has been uneven across member countries and that inflation is on the rise due to high international food and fuel prices. They were also concerned with the continued high levels of unemployment and poverty, and the remaining impediments to stronger and sustained growth. In this context, Directors emphasized the need for stepped-up efforts on structural reforms and infrastructure investment to foster broad-based long-term growth and poverty reduction.

Directors encouraged the authorities to adopt an appropriate policy mix to contain inflationary pressures in the short term. They called for vigilance to the possible secondround effects of the food and fuel price shock. At the same time, they supported reallocating spending toward measures aimed at mitigating the adverse impact of the shock on the most vulnerable segments of the population.

To help ensure that the region's oil wealth is fully translated to improved economic growth and social outcomes, Directors encouraged the authorities to improve the quality 
of social and infrastructure spending through proper selection and implementation of investment projects. They recommended anchoring capital budgets in realistic multi-year investment plans and formulating annual budgets in the context of medium-term fiscal strategies. They also stressed the importance of giving priority to investments in infrastructure and the health and education sectors, and to further strengthening transparency and accountability in the use of oil and other public resources.

Directors underscored the need to promote broad-based, stronger growth over the medium term. They noted that strengthening institutions and streamlining administrative procedures will be critical to improve the business environment. Equally important are efforts to broaden access to credit and remove barriers to regional trade. In this regard, Directors encouraged the authorities to accelerate financial sector reform to address weak banks, strengthen the regulatory framework, increase the capacity of the regional banking supervisor (Central African Banking Commission), and further develop the sector.

Directors noted the staff's assessment that the union's real effective exchange rate, current account positions, and reserves are broadly consistent with external stability. They stressed, however, that compliance with the rule for repatriating export receipts to the Bank of Central African States would be important, and therefore encouraged further strengthening of compliance with union rules.

Public Information Notices (PINs) form part of the IMF's efforts to promote transparency of the IMF's views and analysis of economic developments and policies. With the consent of the country (or countries) concerned, PINs are issued after Executive Board discussions of Article IV consultations with member countries, of its surveillance of developments at the regional level, of post-program monitoring, and of ex post assessments of member countries with longer-term program engagements. PINs are also issued after Executive Board discussions of general policy matters, unless otherwise decided by the Executive Board in a particular case. 
CEMAC: Selected Economic and Financial Indicators, 2007-12

\begin{tabular}{|c|c|c|c|c|c|c|}
\hline & 2007 & 2008 & 2009 & 2010 & 2011 & 2012 \\
\hline & & & & Est. & Proj. & Proj. \\
\hline & \multicolumn{6}{|c|}{ (Annual percent change) } \\
\hline \multicolumn{7}{|l|}{ National income and prices } \\
\hline GDP at constant prices & 5.9 & 4.3 & 2.4 & 5.0 & 5.2 & 4.2 \\
\hline Oil GDP & 3.7 & 3.5 & -4.9 & -2.4 & 1.7 & 3.8 \\
\hline Non-oil GDP & 11.8 & 5.9 & 6.2 & 5.2 & 6.8 & 5.4 \\
\hline Consumer prices (average) $)^{1}$ & 1.0 & 5.7 & 4.7 & 2.7 & 4.1 & 3.9 \\
\hline Consumer prices (end of period) ${ }^{1}$ & 3.0 & 7.1 & 2.9 & 2.9 & 3.5 & 3.0 \\
\hline Nominal effective exchange rate ${ }^{1}$ & 3.1 & 3.2 & -0.1 & -4.1 & $\ldots$ & $\ldots$ \\
\hline \multirow[t]{2}{*}{ Real effective exchange rate ${ }^{1}$} & 0.9 & 5.1 & 2.9 & -3.9 & $\ldots$ & $\ldots$ \\
\hline & \multicolumn{6}{|c|}{$\begin{array}{l}\text { (Annual changes in percent of beginning- } \\
\text { of-period broad money) }\end{array}$} \\
\hline \multicolumn{7}{|l|}{ Money and credit } \\
\hline Net foreign assets & 35.6 & 30.3 & -13.5 & -13.2 & $\ldots$ & $\ldots$ \\
\hline Net domestic assets & -23.3 & -12.3 & 19.5 & 28.0 & $\ldots$ & $\ldots$ \\
\hline \multirow[t]{2}{*}{ Broad money } & 13.9 & 18.4 & 12.2 & 18.4 & $\ldots$ & $\ldots$ \\
\hline & \multicolumn{6}{|c|}{ (In percent of GDP, unless otherwise indicated) } \\
\hline Gross national savings & 24.2 & 26.9 & 18.5 & 20.0 & 29.3 & 28.3 \\
\hline Gross domestic investment & 21.5 & 19.8 & 24.7 & 25.6 & 25.5 & 26.1 \\
\hline Of which public & 8.0 & 8.7 & 13.6 & 11.3 & 12.0 & 12.4 \\
\hline \multicolumn{7}{|l|}{ Government financial operations } \\
\hline Total revenue, excluding grants & 27.8 & 30.6 & 26.0 & 25.5 & 29.3 & 29.4 \\
\hline Government expenditure & 19.5 & 20.3 & 26.9 & 23.3 & 23.1 & 23.8 \\
\hline Primary basic fiscal balance ${ }^{2}$ & 10.4 & 11.7 & 0.9 & 3.6 & 9.3 & 8.9 \\
\hline Basic fiscal balance $^{3}$ & 9.3 & 10.7 & 0.1 & 3.0 & 8.4 & 8.3 \\
\hline Overall fiscal balance, excluding grants & 8.4 & 10.3 & -0.9 & 2.2 & 6.2 & 5.5 \\
\hline Non-oil overall fiscal balance, excluding grants (percent of non-oil GDP) & -17.6 & -22.4 & -25.5 & -23.4 & -23.9 & -22.8 \\
\hline Overall fiscal balance, including grants & 8.7 & 10.4 & -0.6 & 2.5 & 7.6 & 7.5 \\
\hline \multicolumn{7}{|l|}{ External sector } \\
\hline Exports of goods and nonfactor services & 55.7 & 57.2 & 47.3 & 53.0 & 55.8 & 53.7 \\
\hline Imports of goods and nonfactor services & 35.2 & 35.2 & 42.5 & 41.8 & 40.5 & 38.3 \\
\hline Balance on goods and nonfactor services & 20.5 & 22.0 & 4.8 & 11.1 & 15.2 & 15.5 \\
\hline Current account, including grants & 4.7 & 7.2 & -5.5 & -2.8 & 0.7 & 2.0 \\
\hline External Public debt & 18.7 & 11.5 & 10.3 & 6.0 & 5.9 & 6.2 \\
\hline \multicolumn{7}{|l|}{ Gross official reserves (end of period) } \\
\hline In millions of U.S. dollars & 11,937 & 15,662 & 14,354 & 13,658 & $\ldots$ & ... \\
\hline In months of imports of goods and services & 5.2 & 6.9 & 5.7 & 4.5 & $\ldots$ & $\ldots$ \\
\hline In percent of broad money & 120.3 & 124.5 & 112.4 & 101.1 & $\ldots$ & $\ldots$ \\
\hline \multicolumn{7}{|l|}{ Memorandum items: } \\
\hline Nominal GDP (in billions of CFA francs) & 29535.5 & 35294.0 & 30220.8 & 35934.9 & 41658.4 & 43503.3 \\
\hline CFA francs per U.S. dollar, average & 479.3 & 447.8 & 472.2 & 495.3 & 479.2 & 481.6 \\
\hline Oil prices (in US\$ per barrel) & 71.1 & 97.0 & 61.8 & 79.0 & 107.2 & 108.0 \\
\hline
\end{tabular}

Sources: IMF, World Economic Outlook database; and IMF staff estimates and projections.

${ }^{1}$ Using as weights the shares of member countries in CEMAC's GDP in purchasing power parity US\$.

${ }^{2}$ Excluding grants and foreign-financed investment and interest payments.

${ }^{3}$ Excluding grants and foreign-financed investment. 


\section{Statement by Kossi Assimaidou, Executive Director for Central African Economic and Monetary Community (CEMAC) July 20, 2011}

\section{INTRODUCTION}

My Central African Economic and Monetary Community (CEMAC) authorities thank the Executive Board, Management and Staff for their continued support to the union. They welcome today's discussion in the wake of the constructive dialogue held last April in Yaoundé with staff under the 2011 consultations of their common policies. The authorities share the staff's appraisal and recommendations.

CEMAC authorities express also their appreciation to the Fund for the policy advice and technical assistance provided to member countries in their efforts to sustain higher economic growth and fight poverty while maintaining macroeconomic stability. They remain determined to pursue their reform agenda focused on deepening economic regional integration with a view to create a strong and single market for goods, services and labor. In this regard, they look forward to strengthening the cooperation with the Fund and other development partners.

Thanks to Fund technical assistance, considerable progress has been made in financial reforms including the safeguard measures, the governance and accountability of the regional central bank (BEAC) and the regional banking commission (COBAC). My authorities remain committed to the pursuit of the necessary reforms to build strong regional institutions and enhance the financial regulatory and monitoring framework.

In addition, CEMAC authorities are very appreciative of the remarkable ongoing efforts by the Euro area authorities to solve the sovereign difficulties of some member countries given the extent of economic, monetary and financial linkages between the two areas. Moreover, they look forward to an early return to a higher and sustained economic growth in the euro zone, which will benefit CEMAC countries in their development efforts.

\section{ECONOMIC DEVELOPMENTS IN 2010}

The regional economic growth is recovering from the recent global financial crisis and subsequent economic slowdown. The strength of this recovery, supported mainly by public investment and commodity exports, varies across member countries.

Good agricultural harvests and stability in domestic petroleum prices, helped contained the region's inflation. Thanks to high commodity prices and increased demand for the region's exports, the regional current and fiscal balances have improved significantly and international reserves stood in 2010 at 4.5 months of total imports.

Good progress has been achieved in meeting the regional convergence criteria as the volume of noncompliance declined to 6 in 2010 against 9 in 2009. Intensified efforts by CEMAC 
authorities have led all member countries to meet the criteria on public debt and nonaccumulation of government arrears in 2010. However, due notably to capacity constraints, the requirement of a basic fiscal balance was met only by two countries while the inflation threshold of 3 percent was observed by four countries.

Going forward, the CEMAC authorities agree on the need to deepen their reforms designed to ensure fiscal and external sustainability, reform the financial sector while ensuring its stability, and foster stronger non-oil growth to curb unemployment and poverty. Though the regional economic outlook is positive, they are mindful of the risks facing the region, its heavy dependence on oil and other commodity exports as well as the volatility of global food prices with its adverse effects on wages and domestic prices in the region. The authorities remain strongly committed to address these risks with appropriate policies and structural policies going forward.

\section{POLICIES AND STRUCTURAL REFORMS IN 2011}

\section{Fiscal sustainability}

In view of the large investment needs in economic and social infrastructure, the authorities have embarked on a vast public investment program that has widened the non-oil primary deficit. However, this deficit is projected to stabilize at a sustainable level of about 5 percent of non-oil GDP. In this respect, the authorities are committed to anchor public investment in a credible medium-term fiscal strategy. They also share the view that, in a context of fixed exchange regime, there is a need to further enhance their positive fiscal position given that fiscal sustainability and external stability are interlinked.

\section{External sustainability}

The fixed exchange regime has served CEMAC member economies well. In 2010, gross international reserves reached a comfortable level in terms of imports and broad money covers. The authorities are reflecting on the issue of noncompliance with the rule of repatriation of all export receipts. They will maintain close dialogue with the CFA franc zone and the Fund in addressing this issue. Safeguards measures related to the regional central bank have been strengthened and the recent move on the euro interest rate will be helpful.

The authorities also agree on the need to implement an adequate foreign reserves management strategy with a view to meet the desired international reserves sustaining the exchange rate peg to the euro. To this end, they intend to enhance the BEAC institutional and human capacities, with Fund technical assistance.

\section{Structural reforms and non-oil growth}

To adequately fight poverty, the authorities fully understand the need to accelerate non-oil growth. To this end, they are determined to fill the gaps in infrastructure services and improve the business environment while increasing the quality of health and education 
services. In particular, CEMAC authorities plan to implement the measures adopted by the 2007 regional conference on non-oil growth and economic diversification. As analyzed in Appendix 4 of the staff report, capacity, management and institutional constraints continue to impede the effectiveness of public and private investment. My CEMAC authorities hope that they can count on the increased support of development partners to help them tackle those constraints. Finally, my authorities intend to pursue the process of regional integration notably by lifting barriers to internal trade.

\section{BEAC safeguards measures and financial sector reform}

CEMAC authorities have made significant progress in implementing the BEAC action plan aimed at improving governance and internal controls. They share the recommendations made by the recent safeguards monitoring mission to address vulnerabilities identified in the accounting system, internal audit and BEAC national directories. With the adequate Fund technical assistance, the authorities will intensify their efforts to continue monitoring progress on the basis of rolling benchmarks on safeguards measures.

Strengthening financial stability and broadening access to financial services remain key priorities in my CEMAC authorities' efforts to build a strong and sound financial sector for the region. Though the 2006 FSAP continues to guide policy dialogue in this regard, the authorities share the view on the need to align the principal prudential regulations with international best practices and further strengthen their enforcement. In view of the CEMAC's legal and institutional architecture, they are determined to increase COBAC staffing, adopt by year-end the regulations on the resolution of banking crises, and carry out stress tests on the regional banking system.

The authorities' efforts will also focus on improving the institutional environment for the financial sector including the microfinance. They also see merit in furthering efforts to create credit history centers to improve creditor information and the access to financial services for SMEs and households.

\section{CONCLUSION}

My CEMAC authorities will intensify their efforts to pursue and strengthen efforts towards greater regional integration. In this respect, they are appreciative of the support they benefit from the Fund, in the form of policy advice and technical assistance. Continued support of the Fund and other partners will be key to accelerating the implementation of CEMAC's reform agenda and enhancing its institutional and human capacities. 